\title{
Opportunities and Challenges of Microalgal Cultivation on Wastewater, with Special Focus on Palm Oil Mill Effluent and the Production of High Value Compounds
}

\author{
Muhamad Maulana Azimatun Nur ${ }^{1,2} \mathbb{0}$. Anita G. J. Buma ${ }^{1}$
}

Received: 22 September 2017 / Accepted: 26 February 2018 / Published online: 2 March 2018

(c) The Author(s) 2018. This article is an open access publication

\begin{abstract}
South East Asia dominates the production of palm oil worldwide. During the traditional wet processing, palm oil mill effluent (POME) wastewater is generated which poses serious environmental problems. Wastewater treatment using microalgae was initiated recently because of the advantages to lower nutrient content efficiently while the biomass can be utilized as bulk biomass or value added product. In the present review the utilization of wastewater for microalgal cultivation is discussed with particular attention to the feasibility of utilizing POME as microalgal growth medium. Whereas much recent research was focused on the production of bulk biomass, the potential for the production of value-added compounds has not often been addressed. Various strategies of obtaining high-value products are discussed. These include cultivation systems, algal species selection as well as and their growth strategies (autotrophic, heterotrophic, mixotrophic). In addition, potential problems associated with microalgal cultivation on POME will be evaluated. Finally, the concept of using stepwise strategies to obtain high value added product will be proposed.
\end{abstract}

Keywords Palm oil mill effluent $\cdot$ Wastewater $\cdot$ Microalgae $\cdot$ Value added compound $\cdot$ Cultivation

\section{Introduction}

South East Asia is the region with the highest production of palm oil worldwide. Based on FAOSTAT [39], South East Asia coconut palm oil (CPO) production shares $88.6 \%$ of the total world production of 54.38 million ton, increasing from 40.33 to 48.12 million ton between 2010 and 2013. Within this region, Indonesia is currently known as the largest CPO producer, followed by Malaysia and Thailand [39]. Badan Pusat Statistik (BPS) [17] recorded that CPO production in Indonesia rose at $30.14 \%$ between 2010 and 2014 .

During CPO production, a high amount of wastewater is produced, which poses a challenging environmental

Muhamad Maulana Azimatun Nur

lanaazim@upnyk.ac.id

1 Department of Ocean Ecosystems, Energy and Sustainability Research Institute, Faculty of Science and Engineering, University of Groningen, Nijenborgh 7, 9700 CC Groningen, The Netherlands

2 Department of Chemical Engineering, Faculty of Industrial Technology, Universitas Pembangunan Nasional "Veteran" Yogyakarta, J1. SWK 104, Yogyakarta 55283, Indonesia problem. Palm oil milling by wet processing is commonly used in Indonesia and Malaysia [61, 165]. About 1 ton of so-called fresh fruit bunch (FFB) produces 0.66 ton palm oil mill effluent [63]. Upon discharge, the raw POME is a brownish liquid with temperatures ranging between 80 and $90^{\circ} \mathrm{C}$. Further characteristics include: $\mathrm{pH}$ ranging from 4.0 to 5.0, biological oxygen demand (BOD) and chemical oxygen demand (COD) ranging from 15,000 to $30,000 \mathrm{mg} / \mathrm{L}$ and 40,000 to $90,000 \mathrm{mg} / \mathrm{L}$ respectively, high total suspended solids (TSS) between 20,000 and $40,000 \mathrm{mg} / \mathrm{L}$, total dissolved solid (TDS) between 15,000 and 30,000 mg/L, and volatile suspended solids (VSS) between 15,000 and $35,000 \mathrm{mg} / \mathrm{L}$ (Table 1). It is suggested that further treatment should be done to meet standard regulations before POME can be released into the environment (i.e. rivers, lakes) [128, 133, 145].

To treat POME, several mechanical, chemical or biological methods have been developed, as reviewed by Rupani et al. [128] and Liew et al. [83]. These methods include filtration, sedimentation and flocculation. However, to date, the conventional ponding system is the most common method for treating POME $[83,165]$. In Malaysia, more than 85\% of palm oil mills have employed the ponding system for 
Table 1 POME characteristic before and after treatment and standard discharge

\begin{tabular}{llll}
\hline Parameters & Cooling pond $^{\mathrm{a}}$ & Aerobic pond $^{\mathrm{a}}$ & Standard discharge $^{\mathrm{b}}$ \\
\hline Temperature $\left({ }^{\circ} \mathrm{C}\right)$ & $70-80$ & $30-40$ & - \\
$\mathrm{pH}$ & $4.0-5.0$ & 7.0 & $5.5-9.0$ \\
Total COD $(\mathrm{mg} / \mathrm{L})$ & $40,000-90,000$ & $350-1300$ & 100 \\
Total BOD $(\mathrm{mg} / \mathrm{L})$ & $15,000-30,000$ & $100-700$ & 50 \\
TSS $(\mathrm{mg} / \mathrm{L})$ & $20,000-40,000$ & 700 & 400 \\
TDS $(\mathrm{mg} / \mathrm{L})$ & $15,000-30,000$ & - & - \\
VSS $(\mathrm{mg} / \mathrm{L})$ & $15,000-35,000$ & - & 50 \\
Total nitrogen $(\mathrm{TN})(\mathrm{mg} / \mathrm{L})$ & 1494.66 & $456-750$ & 150 \\
Total phosphorus $\left(\mathrm{PO}_{4}-\mathrm{P}\right)(\mathrm{TP})(\mathrm{mg} / \mathrm{L})$ & 315.36 & $68.40-180$ & - \\
Kalium $(\mathrm{mg} / \mathrm{L})$ & $1000-2500$ & $110-924$ & - \\
Magnesium (mg/L) & $250-1000$ & $17-152$ & - \\
\hline
\end{tabular}

${ }^{\text {a} P O M E ~ c h a r a c t e r i s t i c s ~[133] ~}$

${ }^{\mathrm{b}}$ Standard discharge [31]
POME treatment due to its low capital cost [149]. This system employs a series of anaerobic, facultative anaerobic, and aerobic ponds in an open lagoon [75]. Nevertheless, the conventional ponding system has various limitations such as a long hydraulic retention time (HRT), a strong smell, greenhouse gas (GHG) emission, and the large area required for treatment $[63,145]$. Moreover, the POME treated within these ponding systems still does not meet the quality requirements upon standard discharge (Table 1).

Clearly, both POME wastewater production and treatment pose a serious environmental problem. Thus, even if the wastewater quality could be lowered down to its standard regulation, the community near the factory would likely still complain when it is discharged into the environment due to its smell and dark color. Sasongko et al. [133] reported, based on a palm mill with a capacity of 45 tons $\mathrm{FFB} / \mathrm{h}$, located in a 20,000 ha plantation, $360,000 \mathrm{~m}^{3} /$ year of POME is produced. Furthermore, wastewater treatment plants at two particular ponding sites (PTPN V Riau province, and PTPN VII Lampung province, Indonesia) had an average production of $21,454 \mathrm{~m}^{3} /$ month, and an effluent rate of $20,000 \mathrm{~m}^{3} /$ month.

In recent years, the concepts of utilizing waste into more useful products are increasing to meet industrial demands. Valorization is the process of converting waste materials into valuable products. Several researchers reported the valorization of POME into bioenergy, yeast, and enzymes. Louhasakul et al. [86] reported the fermentation by yeast of POME medium thereby accumulating $>33 \%$ of lipid. Iwuagwu and Ugwuanyi [64] utilized POME as a source of carbon and nitrogen for food grade yeast biomass production. Hasanudin et al. [56] reported that the utilization of treated POME as liquid fertilizer increased fresh fruit bunch (FFB) production up to $13 \%$, while Md-Din et al. [94] showed that POME can be utilized as substrate for bacteria to produce poly- $\beta$-hydroxyalkanoates. Finally, POME was found to be suitable substrate for bacteria to produce biomethane [8]. However, based on the recent literature, the utilization of POME by microalgae was mainly focused on lipid production, bulk biomass and wastewater treatment. The present review focuses on the utilization of POME for the production of valuable resources by microalgae. The most recent cultivation strategies, based on different types of wastewater are discussed, whereas strategies to enhance the value added product yield from microalgae growing on POME medium will be proposed.

\section{Microalgae}

Microalgae (including diatoms) are sunlight-driven cell factories that convert carbon into potential biofuels, foods, feeds and high-value bioactives. They can produce valuable lipids, carbohydrates, proteins, pigments, vitamins and other value added products that are promising for present and future feedstocks and pharmaceutical applications in an integrated approach [91, 137]. Microalgae do not require arable land for growth. In addition, they have been shown to be sustained on several types of wastewater [41, 72]. Researchers are interested in applying microalgae within wastewater treatment systems because they can exhibit high production rates all year round, they can efficiently remove nutrients and heavy metals, while simultaneously utilizing $\mathrm{CO}_{2}$ in large amounts [138].

Microalgal cultivation on wastewater effluents has received much attention in recent years, due to their applications and tolerance to a wide variety of nutrient sources [1]. Microalgae are a diverse group of organisms occurring in various natural habitats. While most microalgae are photoautotrophic, some of them are known to grow under mixotrophic or heterotrophic conditions [114]. Environmental growth conditions such as irradiance, temperature, carbon, and macronutrient (nitrogen, phosphorus, silicon) 
and micronutrient (a.o. Fe, $\mathrm{Mn}$ ) availability influence microalgal biochemical composition. Thus, the productivity and biochemical composition of microalgae depend strongly on the mode of cultivation, medium composition, and nutrient profile [48].

\section{Microalgae Cultivation Conditions}

Microalgae commonly grow under photo-autotrophic conditions. Several species are able to switch between photoautotrophic and heterotrophic growth, while in a mixotrophic cultivation both metabolic life styles occur at the same time [114]. Cultivation of microalgae on POME is challenging since the chemical oxygen demand (COD), biological oxygen demand (BOD) and macronutrient levels are high. In addition, the often dark color of POME inhibit light penetration causing light limitation for microalgal photosynthesis and growth [106].

\section{Heterotrophic Growth}

Heterotrophic growth is a process where microalgae utilize organic substrates through aerobic respiration thereby generating energy without light. Under heterotrophic conditions, the cultivation of microalgae has been shown to be successful for commercialization of high-value chemicals, such as cosmetics, pharmaceuticals and food supplements [114]. The economic advantages of heterotrophic growth over photo-autotrophic growth using large-scale microalgae cultivation were summarized a few years ago by Chen [22] and Borowitzka [14]. They reported that high cell population and biomass densities (between 20 and $100 \mathrm{~g} / \mathrm{L}$ ) can be achieved in darkness under heterotrophic cultivation in fermenters. In addition, compared to photo-autotrophic conditions, heterotrophic conditions showed enhanced ammonium and phosphate uptake in synthetic wastewater by Chlorella vulgaris [113]. Moreover, Ummalyma and Sukumaran [150] reported increased lipid production by Chlorococcum sp. when cultivated on dairy effluent wastewater under heterotrophic compared to mixotrophic conditions. The utilization of POME as the growth medium for heterotrophic microalgae is not clear. Several studies reported the cultivation of microalgae on photo-heterotrophic conditions during which microalgae utilize light and organic carbon as the source of energy. Also, Nur and Hadiyanto [104] reported that $C$. vulgaris biomass was enhanced during photo-heterotrophic cultivation by adding D-glucose to POME medium as a co-organic substrate that was mixed with air, containing $\mathrm{CO}_{2}$. Sukumaran et al. [144] reported that the addition of $4 \%$ raw POME to the medium of Spirulina platensis changed the condition into heterotrophic growth due to the dark color that inhibited irradiance exposure. However, specific growth rate, pigments, and biomass were higher during heterotrophic growth compared to autotrophic cultivation that utilized commercial fertilizer without POME addition. It was also demonstrated that micronutrients of POME promoted microalgae growth.

\section{Mixotrophic Growth}

Mixotrophic growth is the process where microalgae use inorganic as well as organic carbon sources in the presence of light. Under this condition, photo-autotrophic and heterotrophic processes may occur simultaneously [70, 154]. Inorganic carbon (i.e. $\mathrm{CO}_{2}, \mathrm{HCO}^{3-}$ ) and macronutrients are utilized through photosynthesis, which is influenced by irradiance quality, quantity and dynamics, while organic compounds (i.e. glucose, carboxylic acid, glycerol) are assimilated through aerobic respiration, which is affected by the availability and type of organic substrate.

Mixotrophic conditions for wastewater treatment were described by Salla et al. [132], and Li et al. [82], showing increased biomass, carbohydrates, lipids, and growth rate for Spirulina platensis and Chodatella sp.. The utilization of wastewater by microalgae under mixotrophic conditions was reviewed by Wang et al. [154]. Overall, the efficiency of nutrient removal $(\mathrm{N}, \mathrm{P})$ from wastewater by microalgae seems higher under heterotrophic and mixotrophic conditions than under photo-autotrophic conditions [82, 115]. Nur and Hadiyanto [104] documented that the biomass and growth rate of $C$. vulgaris were lower when POME was added to the medium as organic carbon source and $\mathrm{NaHCO}_{3}$ as inorganic carbon source compared to the addition of organic carbon (i.e. D-glucose and glycerol). Furthermore, Sukumaran et al. [144] stated that specific growth rate, biomass, and pigment content of S. platensis were higher under mixotrophic conditions compared to heterotrophic conditions.

Apart from the cultivation under mixotrophic or heterotrophic conditions, microalgal growth, biomass composition, production, and nutrient uptake using wastewater are also influenced by biotic factors such as the presence of competitors (zooplankton, bacteria, viruses) [103]. Finally, cultivation strategies of microalgae (batch, fed-batch, and continuous culturing) also affect growth, biomass accumulation, composition and nutrient uptake as reported by several researchers [28, 46, 74]. Table 2 summarizes studies focusing on the production of value-added products by microalgae cultivated on wastewater using the different growth strategies described above.

\section{Microalgae Cultivation Mode}

\section{Fed-Batch Cultivation Mode}

The fed-batch cultivation mode is common in the bioprocess industry. This semi-batch strategy is used to avoid the 
Table 2 Summary of microalgae production under different operational and cultivation

\begin{tabular}{|c|c|c|c|c|c|c|}
\hline Mode & Wastewater source & Microalgae & $\begin{array}{l}\text { Biomass (mg/L/ } \\
\text { day) }\end{array}$ & Nutrient uptake & Product (mg/L/day) & References \\
\hline \multirow[t]{7}{*}{ Continuous } & $\begin{array}{l}\text { Digested anaerobic } \\
\text { starch }\end{array}$ & $\begin{array}{l}\text { Chlorella pyrenoi- } \\
\quad \text { dosa }\end{array}$ & 342.6 & $\begin{array}{l}61.9 \% \text { TOC; } 78.7 \% \\
\text { TN } \\
97.2 \% \text { TP }\end{array}$ & Lipid (43.37) & Chu et al. [27] \\
\hline & Urban wastewater & $\begin{array}{l}\text { Scenedesmus } \\
\text { obliquus }\end{array}$ & 380 & $\begin{array}{l}86.8 \% \mathrm{TN} ; 97.7 \% \\
\mathrm{TP}\end{array}$ & Lipid (105) & Ruiz et al. [126] \\
\hline & $\begin{array}{l}\text { Diluted municipal } \\
\text { wastewater }\end{array}$ & $\begin{array}{l}\text { Scenedesmus sp. } \\
\text { AMDD }\end{array}$ & 300 & - & $\begin{array}{l}\text { Carbohydrate (130) } \\
\text { Protein (120) }\end{array}$ & Dickinson et al. [33] \\
\hline & $\begin{array}{l}\text { Industrial waste- } \\
\text { water }\end{array}$ & Scenedesmus sp. & 900 & $\begin{array}{l}34.6 \mathrm{mg} \mathrm{N} / \mathrm{L} / \text { day } \\
12.7 \mathrm{mg} \mathrm{PO}_{4}^{3-} / \mathrm{L} / \\
\text { day }\end{array}$ & Lipid $(133.2)^{\mathrm{b}}$ & Jebali et al. [65] \\
\hline & $\begin{array}{l}\text { Aquaculture waste- } \\
\text { water }\end{array}$ & C. vulgaris & 42.6 & $\begin{array}{l}\text { TN } 86.1 \%, \text { TP } \\
82.7 \%\end{array}$ & - & Gao et al. [42] \\
\hline & $\begin{array}{l}\text { Muncipal waste- } \\
\text { water }\end{array}$ & Scenedesmus sp. & $234-267$ & TN 99\% TP 99\% & - & McGinn et al. [93] \\
\hline & Digested POME & S. platensis & 267 & $24 \%$ BOD & - & $\begin{array}{l}\text { Suharyanto et al. } \\
\text { [143] }\end{array}$ \\
\hline \multirow[t]{6}{*}{ Fed-batch } & Soybean processing & C. pyrenoidosa & 1070 & $\begin{array}{l}\text { 77.8\% COD; } 88.8 \% \\
\text { TN } \\
7 \text { Gaeo } 0.3 \% \text { TP }\end{array}$ & Lipid (400) & Hongyang et al. [60] \\
\hline & $\begin{array}{l}\text { Digested piggery } \\
\text { manure }\end{array}$ & Desmodesmus sp. & $25^{\mathrm{a}}$ & $\begin{array}{l}94.2 \% \mathrm{TN} ; 88.7 \% \\
\mathrm{PO}_{4}-\mathrm{P}\end{array}$ & Lipid $(6.525)^{\mathrm{b}}$ & Ji et al. [66] \\
\hline & Poultry litter & S. platensis & $126.5^{\mathrm{a}}$ & $\begin{array}{l}\mathrm{NH} 4-\mathrm{N}>99 \% \\
\mathrm{PO}_{4}-\mathrm{P}>99 \%\end{array}$ & $\begin{array}{l}\text { Protein }(66.53)^{\mathrm{b}} \\
\text { Phycocyanin } \\
(15.3)^{\mathrm{b}}\end{array}$ & Markou [92] \\
\hline & & Chorella vulgaris & $127^{\mathrm{a}}$ & $\begin{array}{l}\mathrm{NH}_{4}-\mathrm{N}>99 \% \\
\mathrm{PO}_{4}-\mathrm{P}>99 \%\end{array}$ & Lipid $(53)^{b}$ & \\
\hline & Whey permeate & $\begin{array}{l}\text { Chlorella protothe- } \\
\text { coides }\end{array}$ & $1720^{\mathrm{a}}$ & - & Lipid $(352.6)^{\mathrm{b}}$ & $\begin{array}{l}\text { Espinosa-Gonzalez } \\
\text { et al. [37] }\end{array}$ \\
\hline & Blended wastewater & $\begin{array}{l}\text { Micractinium } \\
\text { inermum }\end{array}$ & 951 & - & - & Park et al. [112] \\
\hline
\end{tabular}

${ }^{\mathrm{a}}$ Calculated from biomass production $(\mathrm{mg} / \mathrm{L})$ and total cultivation time (days)

${ }^{\mathrm{b}}$ Calculated from biomass productivity (mg/L/day) and value added compound (\%)

limitation or inhibition of substrate and the accumulation of toxic compounds (catabolic respiration) during cultivation. The medium is replaced periodically during the process after which the biomass is harvested at the end of the process.

Several researchers reported the advantages of the fedbatch mode in microalgal cultivation. Xie et al. [167] and García-Cañedo et al. [43] reported that by applying autotrophic cultivation, the fed-batch cultivation mode increased pigment content of S. platensis and Scenedesmus incrassatulus as influenced by nutrient addition. Under mixotrophic fed-batch conditions, cellular contents of the long chain poly unsaturated fatty acid EPA was enhanced [168]. Moreover, under heterotrophic fed-batch mode, carbohydrate and protein contents were found to be higher for Neochloris oleoabundans as compared to batch mode [99].

With respect to wastewater treatment, Ji et al. [66] reported that nutrient removal from wastewater by Desmodesmus sp. was higher in fed-batch compared to batch mode, lowering total nitrogen (TN) by 94.2 and
$\mathrm{PO}_{4}-\mathrm{P} 88.7 \%$, while generating $25 \mathrm{mg} / \mathrm{L} /$ day biomass and $6.525 \mathrm{mg} / \mathrm{L} /$ day lipid for 40 days. Under this condition, the alga was cultivated on digested pig manure that contained high levels of ammonium which could negatively impact algal growth. Similar results were found by Markou [92] who reported that ammonia and phosphorus removal were more than $95 \%$ in anaerobically digested poultry litter that contained high ammonia levels. When cultivated in fedbatch mode, $S$. platensis produced $126.5 \mathrm{mg} / \mathrm{L} /$ day biomass, $66.53 \mathrm{mg} / \mathrm{L} /$ day protein and $15.3 \mathrm{mg} / \mathrm{L} /$ day phycocyanin. By employing fed-batch cultivation, the inhibition by excess nutrients in the wastewater could therefore remain limited.

Hongyang et al. [60] reported that the biomass and lipid production of $C$. pyrenoidosa on soybean wastewater that contained high amounts of COD could be enhanced by applying fed-batch mode, resulting in $1070 \mathrm{mg} / \mathrm{L} / \mathrm{day}$ biomass accumulation, and $400 \mathrm{mg} / \mathrm{L} /$ day of lipid productivity. At the same time, the nutrient content was lowered by $77.8 \%$ for COD, $88.8 \%$ for TN, and $70.3 \%$ for TP. 
Espinosa-Gonzalez et al. [37] found that the utilization of high concentrations of glucose and galactose from dairy industry wastewater could be optimized by applying fedbatch cultivation, which resulted in $1720 \mathrm{mg} / \mathrm{L} /$ day of biomass and $352.6 \mathrm{mg} / \mathrm{L} /$ day of lipid. While Park et al. [112] found that the biomass productivity of $M$. inermum was higher in fed-batch cultivation $(950 \mathrm{mg} / \mathrm{L})$, which was supplemented with external nutrient at day 2 , compared to batch control $(800 \mathrm{mg} / \mathrm{L})$. The cultivation was run in an airlift photobioreactor by using a mixture of digested pig wastewater as well as domestic wastewater. This study demonstrated that the fed-batch process may avoid high COD and strong color that could otherwise limit the light penetration in the wastewater medium.

\section{Continuous Cultivation Mode}

In continuous mode, the outflow of harvested biomass and inflow of the fresh medium are maintained in an equal, steady state. Typically, this mode is started after a batch cultivation phase, to obtain a certain cell density. Several researchers employed a continuous cultivation mode to increase the chosen value added product. Sloth et al. [141] and Van-Wagenen et al. [153] employed continuous culturing under mixotrophic conditions to enhance lutein yield. The phycocyanin content of Galdieria sulphuraria was higher in a continuous culture set-up compared to a fedbatch set-up [46]. Coelho et al. [28] compared cultivation modes of Chlorella sp. and found a higher biomass accumulation rate in continuous compared to fed-batch mode. Furthermore, Kumar et al. [74] found a higher biomass and lipid productivity in continuous cultures of Chlorella sorokiniana as compared with fed-batch mode. Similarly, carbohydrate productivity was found to be high under mixotrophic conditions using continuous culturing [Wang et al. 158] and EPA yield was found to be higher during continuous culturing [161] as compared with the fed-batch mode [168]. Beta carotene yield was also increased in continuous mode [175] compared to fed-batch [169] when growing Dunaliella salina under autotrophic conditions.

With respect to wastewater treatment applications, recent studies showed that continuous cultivation can be used to increase the value added content in microalgae while simultaneously lowering the nutrient content in wastewater. Dickinson et al. [33] utilized Scenedesmus sp. grown in municipal wastewater to produce carbohydrate $(130 \mathrm{mg} / \mathrm{L} /$ day) and protein (120 mg/L/day). Furthermore, Jebali et al. [65] utilized industrial wastewater for Scenedesmus sp. cultivation, resulting in $506.7 \mathrm{mg} / \mathrm{L} /$ day carbohydrate and $171.9 \mathrm{mg} / \mathrm{L} /$ day. protein, while the nitrogen and phosphorus were removed at a rate of 34.6 and $12.7 \mathrm{mg} / \mathrm{L} /$ day, respectively. In addition, Ruiz et al. [126] applied the same species and cultivation system on urban wastewater, resulting in $105 \mathrm{mg} / \mathrm{L} /$ day lipid accumulation rate, removing $86.8 \%$ TN, and 97.7\% TP from the wastewater. McGinn et al. 93 found that biomass productivity from the algae cultivated on municipal wastewater was almost twofold greater in continuous mode compared to batch mode, while nutrients could be lowered up to $99 \%$ for both TN and TP. The product accumulation rates of $C$. pyrenoidosa growing on digested anaerobic starch, which contained high levels of organic carbon and a strong white color, was also enhanced by applying continuous cultivation: the microalga produced $43.37 \mathrm{mg} / \mathrm{L} /$ day lipid, and lowered organic carbon content by $61.9 \%$ and total nitrogen and phosphorus by 78.7 and $97.2 \%$ respectively [27]. Similarly, Gao et al. [42] found that the biomass productivity of $C$. vulgaris cultivated in a continuous cultivation on nutrient rich aquaculture wastewater, was 5.8-fold higher compared to batch cultivation. The microalgae produced $42.6 \mathrm{mg} / \mathrm{L} /$ day biomass and removed $86.1 \% \mathrm{TN}$ and $82.7 \%$ TP. Furthermore, Suharyanto et al. [143] cultivated S. platensis on POME medium to produce bulk biomass by applying continuous cultivation. It was reported that $24 \%$ BOD was removed and $0.267 \mathrm{~g} / \mathrm{L} /$ day biomass was produced in this cultivation mode, being higher compared to batch mode.

Overall, continuous microalgal cultivation may have several advantages, but at the same time, it faces multiple challenges during the process as reviewed by Fernandes et al. [40]. However, continuous cultivation strategies seem to be promising in wastewater treatment, since the inhibition and limitation of substrates from wastewater can be avoided. Clearly, biomass and high value product yield benefit from a continuous supply of relatively low levels of nutrients but relatively high, constant irradiance levels, as compared with fed batch mode.

\section{Environmental Factors Affecting Microalgal Cultivation}

Several environmental factors influence microalgal cultivation. In large scale cultivation systems, these factors are ideally manipulated and controlled to obtain the desired product in the most optimal way,

\section{Light}

Photoautotrophic microalgae utilize light as the energy source but during the photosynthetic process $50 \%$ of the energy may be lost in the conversion of solar energy to chemical energy [116]. Algae containing chlorophyll $a$ and $b$, which are the major light harvesting pigments for green algae, primarily absorb blue and red light. Therefore, green algae are found to grow better in blue and red light [140].

Light energy can be stored in the form of carbohydrates or lipids [21]. Several researchers demonstrated the light dependency of carbohydrate storage in algal cells $[20,58]$. 
Subramanian et al. [142] found that storing energy as carbohydrates under high light is energetically less favorable than triacylglycerol (TAG) on a per carbon basis. He et al. [57] also reported that under high light $(400 \mu \mathrm{mol}$ photon/ $\mathrm{m}^{2} / \mathrm{s}$ ), carbohydrate decreased along with an increasing lipid content.

Under nutrient saturated conditions, light is the critical factor for photosynthetic activity. Microalgae require a specific light level to reach their maximum growth rate, which is referred to as the saturating light level. If the light intensity is far above the saturation level, it will inhibit growth (photo-inhibition). On the other hand, if the light intensity is far below the saturation level, growth will be light limited (light-limitation) [76]. Lee and Lee [77] found that the specific removal rate of organic carbon from artificial wastewater under light-dark cycles was higher than under continuous illumination. Yan et al. [170] reported that the nutrient removal from domestic wastewater by $C$. vulgaris was influenced by irradiance wavelength as well as irradiance intensity when applying a light emitting diode (LED). In addition, the dependency of the irradiance responses to remove nutrients from wastewater varied with irradiance level and irradiance period depending on the algal strain [44, 81]. Furthermore, Olguín et al. [110] found that light intensity influenced both the lipid accumulation rate and the lipid profile of S. platensis grown on digested pig waste. Marcilhac et al. [89] found that light intensity affected microalgaebacteria interactions when grown on urban wastewater. In addition, Jiang et al.[67] reported that different light intensities influenced lipid, protein, and carbohydrate content of $C$. vulgaris cultivated on monosodium glutamate wastewater. Several researchers reported the cultivation of microalgae on POME medium by varying light parameters to obtain optimal yields of the desired products. Kamyab et al. [69] stated that the light cycle plays an important role in the lipid production of $C$. pyrenoidosa, cultivated on diluted POME, and continuous irradiance exposure gave the highest growth rate and lipid content compared to exposure to light dark cycles. Furthermore, regular dilution was employed to enhance irradiance in the cultures when cell densities were getting high, as reported by Hadiyanto and Nur 54. In addition, Takriff et al. [147] increased light penetration by adding activated carbon as adsorbent on the POME pre-treatment, thereby decreasing light attenuation.

\section{Temperature}

The effect of temperature on microalgal growth makes it one of the most important environmental factors influencing growth rate and biochemical composition of algae. In one study [123], optimal growth rates for mesophilic species growing outdoors in a wastewater treatment plant were found between 20 and $25{ }^{\circ} \mathrm{C}$, increasing up to $40{ }^{\circ} \mathrm{C}$ for thermophilic strains (Chaetoceros sp., Anacystis nidulans) or decreasing to $17{ }^{\circ} \mathrm{C}$ for psychrophilic strains (Asterionella formosa). Furthermore, Delgadillo-Mirquez et al. [30] found optimum conditions for Chlorella cultivated on wastewater at $25^{\circ} \mathrm{C}$. Zhang et al. [173] reported optimal temperatures between 18 and $25^{\circ} \mathrm{C}$ for Chlorella sp. to produce biodiesel in a wastewater treatment plant.

Decreasing the temperature below the optimal level may increase the unsaturation of lipids as reported by Wang et al. [157]. C. sorokiniana LS-2 grown at a suboptimal temperature of $18{ }^{\circ} \mathrm{C}$ showed enhanced lipid content and mainly contained unsaturated fatty acids. However, lipid productivity was decreased since lower temperatures prolonged the exponential phase and decreased growth rate compared to $26^{\circ} \mathrm{C}$. In addition, sub optimal cultivation temperatures may affect pigments and growth rate. The total carotenoid content of Chlorococcum sp. almost doubled when growth temperature increased from 20 to $35^{\circ} \mathrm{C}$ [84]. Also, astaxanthin production in Haematococcus sp. increased threefold when growth temperature increased from 20 to $30^{\circ} \mathrm{C}$ [148]. Vairappan and Yen [151] reported that growth rate and biomass of Nannochloropsis sp grown on POME medium was affected by cultivation temperature and light. The culture conditions were compared using a $1 \mathrm{~L}$ photobioreactor (Temp: $23{ }^{\circ} \mathrm{C}$, illumination: $180-200 \mu \mathrm{mol}$ photons $/ \mathrm{m}^{2} / \mathrm{s}$ ) and a $10 \mathrm{~L}$ outdoor system (Temp: $26-29^{\circ} \mathrm{C}$, illumination: 50-180 $\mu \mathrm{mol}$ photons $/ \mathrm{m}^{2} / \mathrm{s}$ ). Growth rates were was higher in the photobioreactor but biomass production was higher in the outdoor culture.

\section{Carbon}

For autotrophic growth the supply of inorganic carbon $\left(\mathrm{CO}_{2}\right.$ and $\left.\mathrm{HCO}^{3-}\right)$ is most important. The $\mathrm{CO}_{2-}{ }_{2} \mathrm{CO}^{3}-\mathrm{HCO}^{3-}-\mathrm{CO}_{3}(2-)$ system serves as important buffer in freshwater cultivation systems and may control and maintain specific $\mathrm{pH}$ levels that are suitable for large scale cultivation [47]. Under mixotrophic and heterotrophic cultivation conditions, organic carbon plays an important role in microalgal growth, final yield and lipid accumulation. In general, energy storage molecules, such as lipids and carbohydrates (starch and glycogen) are accumulated under heterotrophic and mixotrophic conditions; therefore, the cellular content of these compounds may be higher than under photo-autotrophic conditions [26].

Various types of wastewater already contain carbon that can be utilized by microalgae [1]. However, a high organic content may limit the growth of certain microalgae in raw wastewater, resulting in a higher retention time [104]. Several researchers reported the supplementation of external carbon in mixotrophic and heterotrophic wastewater cultivation systems to increase biomass, growth rate and nutrient uptake. Perez-Garcia 115 found the highest growth rate 
and ammonium uptake of $C$. vulgaris growing on sterilized municipal wastewater when adding sodium acetate under heterotrophic conditions, while the absence of external carbon supplementation resulted in reduced growth. Gupta et al. [49] reported that the addition of glycerol enhanced biomass productivity and nutrient uptake of $C$. vulgaris and Nannochloropsis oculata, when cultivated on municipal wastewater. Similar results were reported by Ma et al. [87] who reported that nutrient uptake and lipid yield was increased when synthetic wastewater was supplemented with waste glycerol. The addition of inorganic carbon $\left(\mathrm{CO}_{2}\right)$ could also improve the lipid accumulation of microalgae cultivated on domestic wastewater under mixotrophic conditions [32].

Raw POME contains $12.75 \%$ crude protein, $10.21 \%$ crude lipid, and $29.55 \%$ carbohydrate [50]. In most cases, researchers utilized the wastewater at low concentrations to avoid growth inhibition due to toxic levels of a variety of components. Shah et al. [134] utilized $1-20 \% \mathrm{v} / \mathrm{v}$ of raw wastewater, which contained $148-2833 \mathrm{mg} / \mathrm{L} \mathrm{COD}$, to promote the growth of Isochrysis galbana during which 76.4-74.8\%. of the COD could be removed In addition, Sukumaran et al. [144] utilized 1-4\% v/v fresh raw POME in commercial fertilizer by applying fed-batch cultivation to avoid inhibition during the cultivation of $S$. platensis.

It is possible to lower the organic carbon of raw POME by applying anaerobic fermentation processes. During this process, complex carbohydrates, lipids and proteins are degraded. This degradation leads to the formation of $\mathrm{CH}_{4}$, $\mathrm{CO}_{2}$ and carboxylic acid (i.e. acetic acid, propionic acid and butyric acids) [100]. It is reported that digested POME contains acetic acid at concentration ranging between 1170 and $3540 \mathrm{mg} / \mathrm{L}$ (Poh et al. 2010). Several researchers reported that microalgae can be cultivated on higher concentrations of digested POME as compared with undigested POME. Zainal et al. [171] utilized $100 \% \mathrm{v} / \mathrm{v}$ of anaerobically digested POME, which was demonstrated to be rich in organic acid, as growth medium for S. platensis. Here, $90 \%$ of COD was removed. Rajkumar and Takriff, [121] also reported that $S$. platensis and Scenedesmus dimorphus could be cultivated on $90 \% \mathrm{v} / \mathrm{v}$ anaerobically digested POME in an open pond system.

\section{Nitrogen}

In general, microalgae have a limited ability to accumulate nitrogen storage materials when growing under nitrogensufficient conditions. Conversely, cyanobacteria produce sufficient nitrogen storage under high nitrogen concentrations in the form of pigments such as phycocyanin pigments [16]. Recently, growth and biomass yield of microalgae were found to be influenced by the supplementation of different nitrogen compounds and concentrations [122]. Beuckels et al. [12] showed that nitrogen availability affected phosphorus removal of microalgae during wastewater treatment.

It is reported that digested POME contains high total Kjeldahl nitrogen (TKN), but low concentrations of inorganic nitrogen, indicating that it contains high levels of organic nitrogen [133; Poh et al. 2010]. Therefore addition of external inorganic nitrogen is recommended to support algal growth, of which the recommended inorganic $\mathrm{N}: \mathrm{P}$ ratio should be around 6.8-10:1 [109]. Mutanda et al. [101] reported that the addition of $5 \mathrm{mM} \mathrm{NaNO}_{3}$ on postchlorinated wastewater could increase the biomass productivity of Chlorella sp. Hadiyanto et al. [53] supplemented digested POME wastewater with urea fertilizer in order to obtain higher growth rates of Chlorella sp by modifying the nitrogen to phosphorus ratio. Furthermore, Halim et al. [55] reported that the addition of sodium nitrate and dihydrogen phosphate to digested POME, which resulted in 10:1 N $\left(\mathrm{NaNO}_{3}\right) / \mathrm{P}\left(\mathrm{NaH}_{2} \mathrm{PO}_{4}\right)$ molar ratio, could increase the biomass production of Nannochloropsis sp. and remove $90 \%$ $\mathrm{TN}$ and $83 \% \mathrm{TP}$, compared to the control digested POME medium without external nutrient addition. The nutrient removal was higher compared to the study by Shah et al. [135], who reported that $N$. oculata removed $64-75 \%$ of total nitrogen (TN) from raw POME at low concentrations $(1-15 \%)$.

\section{Phosphorus}

Phosphorus is another major macronutrient that influences cellular metabolic processes by forming structural and functional components required for maintenance, growth and survival [38]. Most algal species show a rather consistent phosphorus content, averaging $0.03-3 \%$ of their dry weight [124]. This implies that limiting phosphorus concentrations in the medium results in the repression of photosynthesis [11]. However, previous research reported that microalgae can only utilize phosphate as an inorganic phosphorus source, while phosphite and organic phosphate cannot be used [85]. Therefore, supplementation of phosphate in lagoon wastewater increased the chlorophyll-a content and lipid productivity of consortium microalgae, while alteration of the nitrogen to phosphorus ratio also increased nutrient removal efficiency [78]. In addition, Zhang et al. [172] reported that the supplementation of phosphorus and iron positively influenced biomass yield, lipid yield, and nutrient uptake of $S$. obliquus cultivated on municipal wastewater.

Poh et al. (2010) showed that digested POME contains a high total phosphorus load, mostly consisting of phospholipids and other forms (i.e. methaposphate, orthophosphate, etc). Several researchers reported the reclamation of phosphate from POME by employing microalgae. Rajkumar and Takriff [121] documented a $96.8 \%$ removal of total phosphorus from digested POME by S. platensis. In addition, 
Halim et al. [55] reported that optimizing the nitrogen to phosphorus ratio by adding external nitrogen and phosphorus to a $\mathrm{N}\left(\mathrm{NaNO}_{3}\right) / \mathrm{P}\left(\mathrm{NaH}_{2} \mathrm{PO}_{4}\right)$ molar ratio of 10:1 could improve biomass accumulation of $C$. vulgaris up to $1.5 \mathrm{~g} / \mathrm{L}$. This was confirmed by a $88 \%$ total nitrogen and $91 \%$ total phosphorus removal by using the algae cultivated on $50 \%$ $\mathrm{v} / \mathrm{v}$ digested anaerobic POME wastewater.

\section{Silicon}

Especially for diatoms, silicon is an important macronutrient. Brzezinski [18] reported that marine diatoms, mainly from the genera Thalassiosira and Chaetoceros, have a silicon to nitrogen atomic ratio around 1 . Silicate plays a vital role in diatom cell wall formation and deoxyribonucleic acid (DNA) synthesis during the metabolic process [29]. Roessler [125] reported that silicon deficiencies influenced the accumulation of neutral lipids in Cyclotella cryptica, and silicon limitation also resulted in a 5\% shift in lipid chain length, from $\mathrm{C} 18$ to $\mathrm{C} 16$ fatty acids [6]. In addition, lipid accumulation was found to be influenced by silicate depletion both in autotroph $[129,163]$ and heterotroph cultures [160]. Graham et al. [45] concluded that the presence of silicon was important when freshwater diatoms (genera Cyclotella, Aulacoseira, Fragilaria, Synedra) were cultivated on wastewater. The amount of silicon present or added to the medium for diatoms should be 17.5 times the mass of phosphorus for optimal utilization of phosphorus and nitrogen in wastewater medium.

\section{Micronutrients}

Several micronutrients are important for microalgal growth and composition. Iron plays a vital role in cellular biochemical composition because of its redox properties and implications in fundamental processes such as photosynthesis, respiration, nitrogen assimilation and DNA synthesis [88]. To date, $\mathrm{Fe}$ is supplied in mass cultivation systems in a chelated form such as ferric citrate $\left(\mathrm{C}_{6} \mathrm{H}_{5} \mathrm{FeO}_{7}\right)$, ferric EDTA $\left(\mathrm{FeCl}_{3}\right.$-EDTA) or ferrous ascorbate [15]. Several researchers reported the effect of iron on microalgal pigments such astaxanthin, beta-carotene, and fucoxanthin $[159,19,97$, 35]. Recent studies showed that the addition of iron in wastewater enhanced biomass yield and nutrient uptake of Chlorella sp [174]. Similar results were obtained by Zhang et al. [172] who found that the addition of $\mathrm{FeCl}_{3} \cdot 6 \mathrm{H}_{2} \mathrm{O}$ to municipal wastewater influenced biomass yield, lipid yield, and nutrient uptake of $S$. obliquus. However, Habib et al. [51] measured the micronutrient concentration of digested POME and concluded that POME contains sufficient levels of micronutrients such as potassium $(963 \mathrm{mg} / \mathrm{L})$, calcium (531 mg/L), aluminium (136 mg/L), magnesium $(87 \mathrm{mg} / \mathrm{L})$, iron $(79 \mathrm{mg} / \mathrm{L})$, sodium $(69 \mathrm{mg} / \mathrm{L})$, and zinc $(48 \mathrm{mg} / \mathrm{L})$. These micronutrients influenced the poly unsaturated fatty acid (PUFA) profile of $C$. vulgaris growing on different POME concentration.

\section{Salinity}

Salinity affects the production of pigments in microalgae. For example, highest chlorophyll-a and total carotenoids productivity was found at a salinity of 2 ppt for Dunaliella viridis [62]. Xia et al. [166] compared four types of salts $\left(\mathrm{NaCl}, \mathrm{NaHCO}_{3}, \mathrm{NaS}_{2} \mathrm{O}_{3}\right.$ and Na-Acetic acid) with respect to lipid production in Desmodesmus abundans, and the highest production was obtained for $\mathrm{NaCl}$. In addition, in Dunaliella tertiolecta ATCC 30,929, a high salinity increased lipid content up to $70 \%$ [146]. In the freshwater alga Scenedesmus sp., lipid production was stimulated by $\mathrm{NaCl}$ [130]. However, excess salinity stress in the cultivation medium inhibits photosynthesis which further reduces the biomass and net lipid productivity. As discussed by Minhas et al. [96], salinity stress tends to remarkably affect the fatty acid profile of microalgae.

With respect to wastewater utilization, Salama et al. [131] documented that Chlamydomonas mexicana exhibited a higher specific growth rate when 100 and $200 \mathrm{mmol} / \mathrm{L} \mathrm{NaCl}$ was supplemented to municipal wastewater, whereas nitrogen was completely removed and $38 \%$ of lipid was obtained when $400 \mathrm{mmol} / \mathrm{L} \mathrm{NaCl}$ was added.

\section{$\mathrm{pH}$}

The efficient growth of microalgae in wastewater depends on critical variables, including $\mathrm{pH}$, temperature, and the availability of nutrients [117]. It is well known that digested POME and other wastewaters contain nitrogen mostly in the form of ammonia [92, 133, Poh et al. 2010, 92]. Yet, the equilibrium between ammonia $\left(\mathrm{NH}_{3}\right)$ and ammonium $\left(\mathrm{NH}_{4}{ }^{+}\right)$is depended on $\mathrm{pH}$ and temperature [73]. It is reported that the ratio of ammonia to ammonium increases 10 -fold for each unit increase in $\mathrm{pH}$ [36].

Some researchers reported the negative effects of ammonia on the growth of microalgae related with $\mathrm{pH}$. Abeliovich and Azov [3] found that ammonia at a concentration over $2 \mathrm{mM}$ and a pH over 8 in a high-rate sewage oxidation pond inhibited the growth of $S$. obliquus. Furthermore, Belkin and Boussiba [10] reported that the growth of Arthospira platensis was inhibited by $50 \%$ due to high ammonia concentrations up to $140 \mathrm{mg} / \mathrm{L}$ at a $\mathrm{pH}$ of 10. Khoo et al. [71] reported that the growth of $C$. vulgaris, which was cultivated on municipal wastewater, was highly influenced by initial $\mathrm{pH}$. Under acidic ( $\mathrm{pH} 2)$ or alkaline (9 or 11) $\mathrm{pH}$, growth rates were low. In contrast, highest biomass productivity and nutrient removal efficiency were recorded at $\mathrm{pH}$ 
3. Furthermore, Hodaifa et al. [59] reported that the specific growth rate, protein, and chlorophyll content of S. obliquus were high when the medium (olive-mill wastewater) was maintained at a constant $\mathrm{pH}$ value of 7.0. Yet, PUFAs and essential fatty acids increased when the $\mathrm{pH}$ was set at nine.

\section{High-Value Products from Microalgae}

Generally, microalgae are cultivated on wastewater to obtain carbohydrates, lipids, and proteins which are mainly focused on fuel and animal feed. However, microalgae are known to produce high value bioactive compounds, which may have different pharmaceutical and cosmetic applications. Table 3 summarizes the presently available studies of microalgal cultivation on POME resulting in value-added products.

Pigments obtained from microalgae could be useful for food colorants, vitamins, cosmetics and pharmaceutical applications [9]. Sukumaran et al. [144] found $1.8 \mathrm{~g} / \mathrm{L}$ biomass and $0.216 \mathrm{~g} / \mathrm{L}$ phycocyanin from $S$. platensis cultivated after the addition of $1 \%$ raw POME using fed-batch mode. The cultivation was carried out in an outdoor openpond system and therefore temperature and light intensity were variable at $25-40{ }^{\circ} \mathrm{C}, 800 \sim 1600 \mu \mathrm{mol}$ photons $/ \mathrm{m}^{2} / \mathrm{s}$, respectively.

In addition to pigments, microalgae may contain high levels of (Long Chain) Poly Unsaturated Fatty Acids (PUFA), which are suitable as a replacement source of fish fatty acids [79]. Vairappan and Yen [151] cultivated Isochrysis sp on $5 \%$ digested POME supplemented with external nutrient in an outdoor batch cultivation at $26-29^{\circ} \mathrm{C}$ and $50-180 \mu \mathrm{mol}$ photons $/ \mathrm{m}^{2} / \mathrm{s}$ intensity system for 7 days. The algae produced $91.7,48.41$, and $23.84 \mathrm{mg} / \mathrm{m}^{2} /$ day of biomass, lipids and PUFAs, respectively. Nur et al. [105] documented that C. vulgaris was more suitable to be cultivated on digested POME wastewater compared to $S$. platensis and D. salina. The algae were cultured for 13 days on 10-30\% digested POME in laboratory batch cultivation mode, under $24 \mathrm{~h}$ continuous light irradiation (4000 lx), and the temperature was set to $26-28{ }^{\circ}$ C. C. vulgaris produced 12.6 and $11.22 \mathrm{mg} / \mathrm{L} /$ day of lipids and carbohydrates, respectively. On the other hand, S. platensis could produce $100 \%$ fatty acid methyl ester (FAME) which is suitable as a source of biodiesel, while the FAME in D. salina and C. vulgaris was 14.77 and $37.38 \%$, respectively. Nur et al. [106] also recorded that $B$. braunii could produce 17.63 and $18.11 \mathrm{mg} / \mathrm{L} /$ day of lipid and carbohydrate with the addition of $250 \mathrm{mg} / \mathrm{L} \mathrm{COD} \mathrm{sub-}$ strate from digested POME. The cultivation was maintained at $5000 \mathrm{~lx}$ ( $24 \mathrm{~h}$ duration), $28{ }^{\circ} \mathrm{C}$ temperature, $0.15 \mathrm{M}$ salinity, and $\mathrm{pH} 6.8-7.2$, The lipid contained $4.25,37.29$, and $2.1 \%$ of $\mathrm{C} 16, \mathrm{C} 23$, and $\mathrm{C} 18$, respectively.

Shah et al. [134] cultivated I. galbana and Pavlova lutheri on raw POME, diluted with different fractions of filtered sea water, showing that the POME fraction influenced the lipid content of the algae.

Furthermore, $N$. oculata and T. suecica on raw POME, diluted with different fractions of filtered sea water, showing that the POME fraction influenced the lipid content of the algae. Under optimal conditions (10\% POME), the PUFA content was 9.07 and $8.88 \%$ for the two species, while the biomass produced was 0.15 and $0.14 \mathrm{~g} / \mathrm{L} / \mathrm{day}$ respectively [135].

Habib et al. [51] revealed that the addition of $10 \%$ digested POME positively influenced the PUFA composition of $C$. vulgaris as compared with commercial medium due to the high micronutrient content of the wastewater. They also reported that $985 \mathrm{~g} / \mathrm{L}$ biomass could be produced under these conditions, consisting of $18.3 \%$ lipids, $28.7 \%$ proteins, $26.1 \%$ carbohydrates and $15 \%$ linolenic acid. Although several studies have focused on high value compound production using POME wastewater, more work is urgently needed, especially utilizing species from other taxonomic groups. For example, the application of diatoms in cultivation studies using POME has not been addressed so far. Diatoms may contain much higher levels of the fish fatty acids (LCPUFAs) EPA and DHA as compared with the most common species used for cultivation (as given in Table 3) Boelen et al. [13] reported that EPA and DHA production rates were highly species specific. The highest EPA productivity was found in the diatom Chaetoceros brevis $(174 \mu \mathrm{g} / \mathrm{L} / \mathrm{day})$, while DHA productivity was highest in Emiliania huxleyi (164 $\mu \mathrm{g} / \mathrm{L} /$ day). Moreover, diatoms contain high levels of the carotenoid fucoxanthin, which may have significant health benefits. In general, a limited number of species (Table 3) were grown on POME medium with the aim to produce pigments and other valuable compounds. Since the type and level of high value compounds produced are highly dependent on the species cultivated, more studies are therefore required to focus on species-specific differences in POME cultivation success related with value added product yield.

\section{Pretreatment of Wastewater for Microalgal Growth}

To optimize the utilization of wastewater for microalgal growth, several pretreatment methods have been proposed. These pretreatments were done to lower COD, BOD, turbidity, suspended solids, and microorganisms. Table 4 summarizes several pretreatment methods using thermal, chemical, mechanical, and biological processes. Hadiyanto et al. [52] utilized water lily in the process to lower COD and BOD content from POME as the medium for S. platensis. Takriff et al. [147] reported an increase in S. dimorphus biomass in pretreated POME medium by using activated carbon to increase the light penetration in the medium. Nwuche 


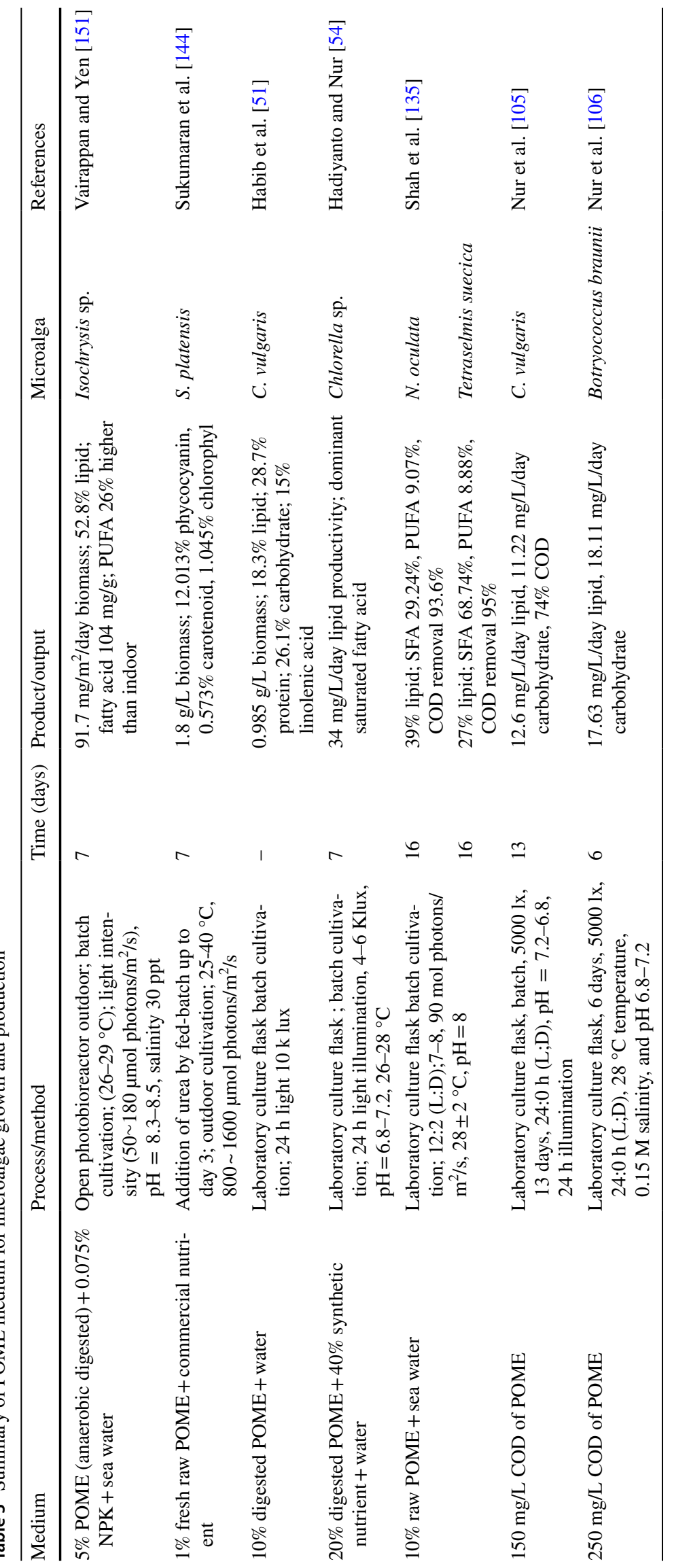


Table 4 Pretreatment methods in wastewater for microalgae medium

\begin{tabular}{|c|c|c|c|c|c|}
\hline Input media & Pretreatment method & Microalga & Yield or Productivity & Final effluent & References \\
\hline Digested POME & Water lily (8 days) & S. platensis & $0.945 \mathrm{~g} / \mathrm{L}$ biomass & $96.9 \% \mathrm{COD} ; 80 \% \mathrm{TN}$ & Hadiyanto et al. [52] \\
\hline Digested POME & $\begin{array}{l}\text { Addition of activated } \\
\text { carbon }\end{array}$ & S. dimorphus & $0.17 \mathrm{~g} / \mathrm{L}$ biomass & - & Takriff et al. [147] \\
\hline \multirow[t]{2}{*}{ Raw POME } & \multirow[t]{2}{*}{$\begin{array}{l}\text { Filtration, centrifuga- } \\
\text { tion and autoclave }\end{array}$} & I. galbana & $\begin{array}{l}0.142 \mathrm{mg} / \mathrm{L} / \text { day bio- } \\
\text { mass }(26.3 \% \text { lipid })\end{array}$ & $\begin{array}{c}\text { 77.4\% COD; } 58.8 \% \\
\text { TOC; } 57.4 \% \text { TN }\end{array}$ & \multirow[t]{2}{*}{ Shah et al. [134] } \\
\hline & & Pavlova lutheri & $\begin{array}{l}0.130 \mathrm{mg} / \mathrm{L} / \text { day bio- } \\
\text { mass ( } 34.5 \% \text { lipid) }\end{array}$ & $\begin{array}{c}80.1 \% \mathrm{COD} ; 62.3 \% \\
\text { TOC; } 61.3 \% \mathrm{TN}\end{array}$ & \\
\hline Digested POME & Filtration $(0.22 \mu \mathrm{m})$ & C. sorokiniana & $\begin{array}{l}12.4 \mathrm{mg} / \mathrm{L} / \text { day lipid } \\
0.134 \mathrm{mg} / \mathrm{L} / \text { day chlo- } \\
\text { rophyll }\end{array}$ & $63 \% \mathrm{COD}$ & Nwuche et al. [107] \\
\hline Centrate wastewater & Autoclave $\left(121^{\circ} \mathrm{C}\right)$ & Chlorella sp. & $1.175 \mathrm{~g} / \mathrm{L}$ biomass & $\begin{array}{l}90.3 \% \mathrm{COD}, 89.9 \% \\
\text { total nitrogen }\end{array}$ & Li et al. [80] \\
\hline \multirow[t]{2}{*}{$\begin{array}{l}\text { Secondary municipal } \\
\text { wastewater }\end{array}$} & Filtration $(0.2 \mu \mathrm{m})$ & \multirow[t]{2}{*}{ Chlorella sp. } & $22.9 \mathrm{mg} / \mathrm{L} /$ day lipid & $\begin{array}{l}92 \% \mathrm{TN} \\
86 \% \mathrm{TP}\end{array}$ & \multirow[t]{2}{*}{ Cho et al. [25] } \\
\hline & $\begin{array}{l}\text { UV-B irradiation } \\
(3 \mathrm{~min})\end{array}$ & & 13 mg/L/day lipid & $\begin{array}{l}75 \% \mathrm{TN} \\
84 \% \mathrm{TP}\end{array}$ & \\
\hline $\begin{array}{l}\text { Diluted synthetic } \\
\text { wastewater }\end{array}$ & Electrolysis (2 h) & C. vulgaris & $1.087 \mathrm{~g} / \mathrm{L}$ biomass & $\begin{array}{l}83.7 \% \text { TOC; } 99.3 \% \\
\text { NH4-N }\end{array}$ & Wang et al. [156] \\
\hline \multirow[t]{2}{*}{ Diluted dairy manure } & $\begin{array}{l}\text { Centrifuge } \\
\quad(10,000 \mathrm{rpm} 15 \mathrm{~min})\end{array}$ & C. vulgaris & $\begin{array}{l}20.6 \mathrm{mg} / \mathrm{L} / \text { day bio- } \\
\text { mass }\end{array}$ & - & \multirow[t]{2}{*}{ Shi et al. [136] } \\
\hline & Autoclave $\left(121^{\circ} \mathrm{C}\right)$ & & $\begin{array}{l}47.2 \mathrm{mg} / \mathrm{L} / \text { day bio- } \\
\text { mass }\end{array}$ & - & \\
\hline \multirow[t]{2}{*}{ Dairy manure } & $\begin{array}{l}\text { Chemical addition } \\
\mathrm{NaOCl} \\
(30 \mathrm{ppm})\end{array}$ & C. vulgaris & 44 mg/L/day lipid & $\begin{array}{c}63.1 \% \mathrm{COD} ; 77.8 \% \\
\mathrm{TKN} ; 99.5 \% \mathrm{TP}\end{array}$ & \multirow[t]{2}{*}{ Qin et al. [120] } \\
\hline & $\begin{array}{l}\text { UV irradiation } \\
(15 \text { min })\end{array}$ & & $31.5 \mathrm{mg} / \mathrm{L} /$ day lipid & $\begin{array}{r}74 \% \text { COD; } 95.4 \% \\
\text { TKN; } 94.8 \% \text { TP }\end{array}$ & \\
\hline $\begin{array}{l}\text { Diluted olive oil mill } \\
\text { effluent }\end{array}$ & $\begin{array}{l}\text { Chemical addition } \\
\mathrm{NaOCl}(12.5 \mathrm{~g} / \mathrm{L})\end{array}$ & S. platensis & $1.69 \mathrm{~g} / \mathrm{L}$ biomass & $\begin{array}{c}65.53 \% \text { COD; } 100 \% \\
\text { Phenol; } 100 \% \text { TP }\end{array}$ & Markou et al. [90] \\
\hline Domestic wastewater & $\begin{array}{l}\text { Chemical addition } \\
\mathrm{NaOCl}(0.4 \mathrm{mg} / \mathrm{L})\end{array}$ & Chlorella sp. & $93.8 \mathrm{mg} / \mathrm{L}$ biomass & - & Mutanda et al. [101] \\
\hline Piggery wastewater & $\begin{array}{l}\text { Bubbled with air (5\% } \\
\left.\mathrm{CO}_{2} 100 \mathrm{ml} / \mathrm{min}\right)\end{array}$ & $\begin{array}{l}\text { Desmodesmus sp. } \\
\text { CHX1 }\end{array}$ & $118.2 \mathrm{mg} / \mathrm{L} /$ day lipid & $87.3 \% \mathrm{TN} ; 93.1 \% \mathrm{TP}$ & Cheng et al. [23] \\
\hline \multirow[t]{3}{*}{$\begin{array}{l}\text { Digested Poultry } \\
\text { manure effluent }\end{array}$} & $\begin{array}{l}\text { Electrolysis }(+2 \mathrm{~g} / \mathrm{L} \\
\mathrm{NaCl} ; 15 \mathrm{~V} ; 2 \mathrm{~h})\end{array}$ & C. vulgaris & $0.53 \mathrm{~g} / \mathrm{L}$ biomass & $\begin{array}{l}99.7 \% \text { NH4-N } \\
91.6 \% \mathrm{TP}\end{array}$ & \multirow[t]{3}{*}{ Wang et al. [155] } \\
\hline & $\begin{array}{l}\text { Centrifugation } \\
\quad(8000 \mathrm{rpm} 15 \mathrm{~min})\end{array}$ & & $0.56 \mathrm{~g} / \mathrm{L}$ biomass & $\begin{array}{l}99.5 \% \mathrm{NH} 4-\mathrm{N} \\
99.3 \% \mathrm{TP}\end{array}$ & \\
\hline & $\begin{array}{l}\text { Autoclave }\left(120^{\circ} \mathrm{C}\right. \\
30 \mathrm{~min})\end{array}$ & & $0.48 \mathrm{~g} / \mathrm{L}$ biomass & $\begin{array}{l}98.3 \% \text { NH4-N } \\
98.3 \% \text { TP }\end{array}$ & \\
\hline
\end{tabular}

et al. [107] and Cho et al. [25] used a filtration method to remove contaminants from wastewater which resulted in the increase of lipid productivity in Chlorella sp.. Autoclaving was applied by Shi et al. [136] and Li et al. [80]; this resulted in an increase in microalgal biomass yield and productivity. In contrast, Wang et al. [155] obtained a lower microalgal biomass when the wastewater was pretreated using autoclaving. Here, autoclaving was not found to be effective for lowering the turbidity in the medium. A similar pretreatment was employed by Shah et al. [134] by combining autoclaving, centrifugation and filtration. Following this procedure, marine microalgae were found to accumulate high lipid levels when cultivated on the treated POME. Other pretreatment processes include electrolysis [156], 155], centrifugation [136, 155] and sparging with air [23].

Researchers also reported the pretreatment process by adding chemical agent or activated carbon to coagulate and adsorb the color. Activated carbon addition was found to be more effective to adsorb the dark color compared to the addition of starch and rice powder as a coagulator. Mutanda et al. [101] described the application of $\mathrm{NaOCl}$ in wastewater medium to lower turbidity. While Markou et al. [90] utilized $12.5 \mathrm{~g} / \mathrm{L} \mathrm{NaOCl}$ as pretreatment of olive oil mill effluent, which resulted in no negative impact on microalgae. Nevertheless, Qin et al. [120] showed that the addition of $30 \mathrm{ppm} \mathrm{NaOCl}$ gave a better pretreatment for 
dairy manure rather than UV irradiation. Overall, any pretreatment process of wastewater is highly recommended to enhance microalgal growth and production.

\section{Future Prospects}

Microalgae have a great potential to produce food, feed, fuel, fine chemicals and fertilizers on a commercial scale, in spite of facing several issues [41, 95, 127]. Apart from biofuel production, microalgae may serve as a potential renewable source for other commercial applications [95]: (a) Environmental applications such as wastewater treatment and $\mathrm{CO}_{2}$ mitigation; (b) Human nutrition; (c) Animal and aquatic feed; (d) Cosmetics production; (e) High-value compounds such as fatty acids; (f) Pigments such as beta-carotene, astaxanthin, fucoxanthin, phycobiliproteins; (g) Stable biochemicals; (h) Biofertilizer; (i) Drug synthesis for antimicrobial, antiviral and anticancer treatments.

To date, the value added production by microalgae still faces high production costs compared to other sources [162]. For example, Molina-Grima et al. [98] reported that the production of high-purity Eicosapentaenoic Acid (EPA) from the diatom Phaeodactylum tricornutum requires a total production cost of US $\$ 4602 / \mathrm{kg}$, with $60 \%$ of the costs arising from the recovery process and $40 \%$ from the biomass processing. These costs should be reduced by $80 \%$ to be economically viable. However, the worldwide demand of EPA is 300 ton per annum [139].

Microalgae are considered to be promising for future raw feedstock because of their potency to produce derivative products in biorefinery processes by utilizing wastewater [2]. Biorefinery techniques are necessary to exploit all products from microalgae after cultivation. The main problem is to separate the different fractions without damaging one or more of the product fractions [152]. Microalgae are mainly composed of carbohydrates, lipids and proteins, and other components such as pigments. The combination of the biorefinery concept in downstream processing and utilization of wastewater for microalgal growth could reduce the production costs in the microalgae industry. Eventually, the whole cell could be utilized for food, feed, fuel, and fertilizer product, and wastewater could replace the (environmental) costs of synthetic nutrient additions. In addition, screening of microalgae based on the biochemical composition for efficient biomass production from wastewater treatment also plays a vital role in commercial applications [4].

Despite the high nutrient levels, the utilization of POME as growth medium for microalgae at industrial scale is still challenging. First, the high organic compounds, consisting of tannins, lignin, and phenolic compounds could negatively affect growth [51, 102, 105]. The dark coloration due to high concentrations of suspended solids could inhibit light penetration, which is a critical factor for photosynthetic growth $[34,106,111]$.

Moreover, the presence of heterotrophic bacteria may affect biomass productivity $[24,80]$. The low $\mathrm{pH}$ and salinity of the wastewater needs to be adjusted before it can be used as growth medium for alkaline microalgae such as $S$. platensis or marine microalgae, such as P. tricornutum which contains high levels of bioactive compounds. In addition, in some cases, the heavy metals in POME could prevent utilization of the bioactive compounds from the algae as pharmaceutical, cosm Enhanced palm oil mill etic or human consumption unless the metals are carefully removed [7].

However, the conditions as mentioned above could be prevented by employing some pretreatment process to lower COD, color, and heavy metals from the POME as described previously in Sect. 3. To increase the salinity, the cultivation might be relocated to seashore areas. Furthermore, the wastewater could be blended with hypersaline wastewater generated from industrial activities, such as chemical manufacturing, and oil production [164], to make the cultivation become more feasible for marine microalgae.

As stressed earlier, bioenergy and high-value biochemical production from the palm oil industry could benefit from the combination of wastewater treatment procedures [2]. Figure 1 shows the proposed concept for the utilization of POME wastewater as the growth medium for microalgae with the aim to obtain value added products and bioenergy feedstock. To optimize wastewater utilization, pretreatment processes of the raw source need to be employed. Several researchers reported that a high turbidity from the wastewater may induce heterotrophic or mixotrophic growth that benefits biomass production, lipid accumulation, and nutrient uptake [5, 49]. Furthermore, to provide $\mathrm{CO}_{2}$ for mixotrophic cultivation, and lowering COD and BOD content in POME, the wastewater could be processed in an anaerobic fermentor, resulting in methane that could be used directly as an energy source. A previous report showed that the biomethane production could be enhanced by employing a co-culture of Chlorella sp coupled to palm oil empty fruit bunch. This resulted in a biogas production rate of $0.128-0.129 \mathrm{~m}^{3 /}$ $\mathrm{kg} \mathrm{COD/day} \mathrm{and} \mathrm{a} \mathrm{biomethane} \mathrm{yield} \mathrm{of} 5256.8-5295.8 \mathrm{~mL} / \mathrm{L}$ $\mathrm{POME} /$ day. The methane yield was 1.4 -fold higher compared to the process without microalgae [8].

Another proposed strategy is the cultivation of specific microalgae-bacteria consortia in the treatment of wastewater to enhance the bioactive compound (Fig. 1). Wastewater provides ideal media for bacterial growth and decomposition of organic matter in the presence of oxygen. However, only several types of bacteria can efficiently remove inorganic nutrients such as phosphorus, which is usually the main cause of eutrophication of freshwater ecosystems [111]. During this processes, microalgae provide oxygen for aerobic bacteria 


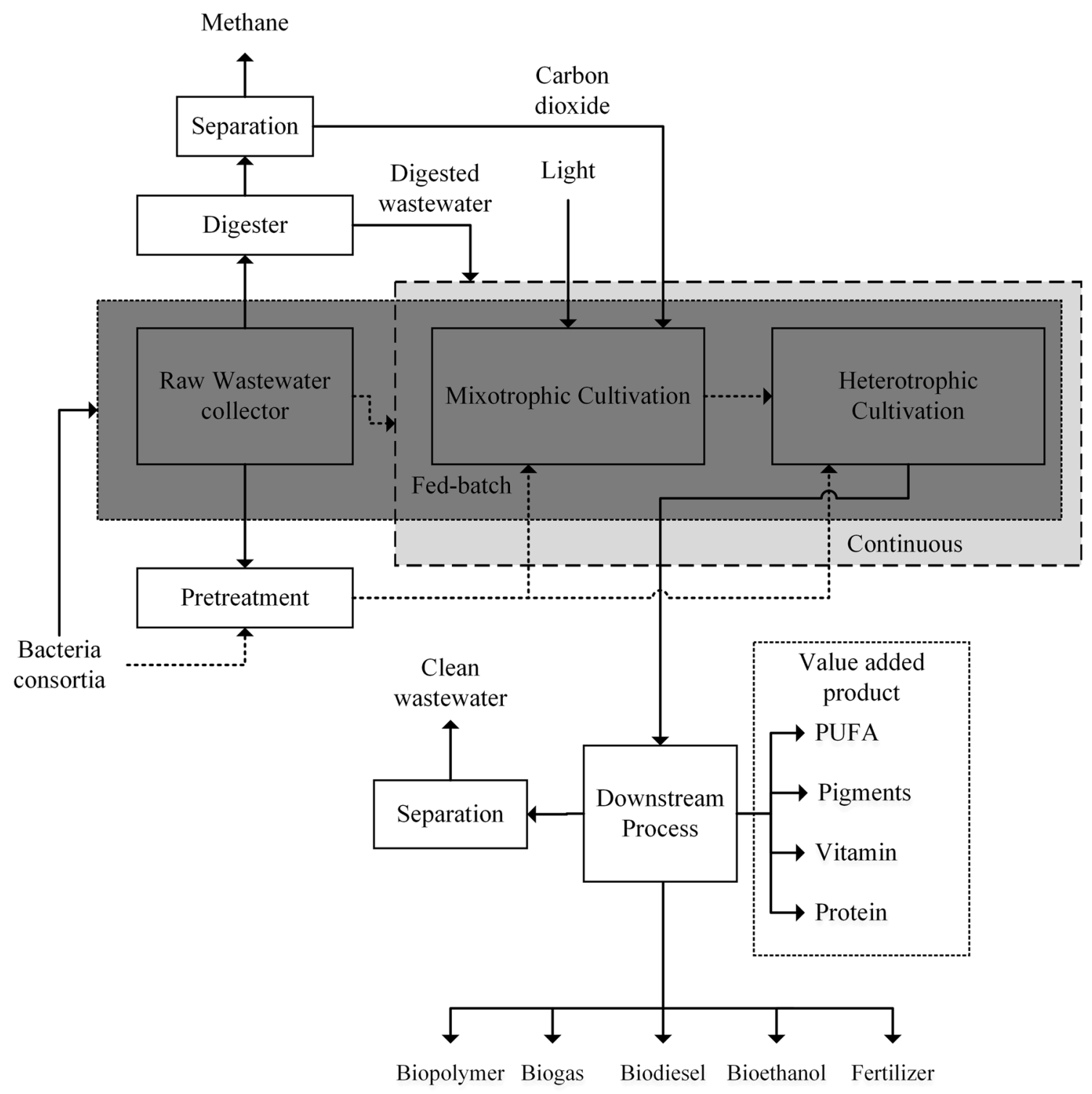

Fig. 1 Proposed concept for the utilization of wastewater for microalgal medium in order to produce value added compounds

to degrade organic matter and consume the carbon dioxide produced by bacterial respiration. Thus, these systems are an economical alternative to conventional aerobic treatments of wastewater [30, 119]. For example, Delgadillo-Mirquez et al. [30] demonstrated nitrogen and phosphate removal from wastewater using co-cultures of microalgal and bacterial consortia. However, bacteria may compete with microalgae for the available nutrients such as $\mathrm{N}$ and $\mathrm{P}$, producing metabolites that are inhibitory to microalgal growth [68]. Furthermore, a strategy is proposed to utilize fed-batch or continuous cultivation modes to avoid inhibitiorn by toxic levels of certain compounds in POME wastewater. Here, bacterial consortia could be injected in the fed-batch mode to increase COD and BOD efficiencies. As an alternative, raw wastewater could be utilized in a continuous mode to increase biomass and products from microalgae.

To optimize value added product accumulation in microalgae, a two-step cultivation process seems promising. In the first step, microalgae could be cultivated under mixotrophic conditions to increase biomass productivity. In the second step, the culture could be transferred to heterotrophic conditions to increase compound yield. A similar strategy was proposed by Ogbonna et al. [108] who employed a twostep cultivation of autotrophic and heterotrophic conditions to increase the protein and chlorophyll content of $C$. pyrenoidosa C-212. With this system, the biomass concentration was recorded at $14 \mathrm{~g} / \mathrm{L}$ containing $60.1 \%$ protein and $3.6 \%$ chlorophyll. Furthermore, Van-Wagenen et al. [153] 
employed cyclic autotrophic/heterotrophic cultivation of $C$. sorokiniana with the addition of acetate as external substrate. This resulted in higher biomass productivity up to $1.2 \mathrm{~g} / \mathrm{L} /$ day compared to the mixotrophic or autotrophic condition. Other solutions to enhance biomass and product yields might be to modify and/or control the environmental factors that were discussed in Environmental factors affecting microalgal cultivation Finally, it should be considered that the type of cultivation system such as open pond cultivation versus closed cultivation using photo-bioreactors could also influence the growth, biomass, and products. It may be clear that more research must be done to further optimize wastewater (including POME) utilization for high-value product generation by microalgae. However, is has become clear from the research executed over the past decennia, that optimization should be done based on a combination of approaches (choice of species, cultivation conditions, cultivation modes, nutrient ratio's, pretreatments etc.) before valorization could become economically feasible.

\section{Concluding Remarks}

Recent information on oil palm production faces serious environmental problems in the South East Asian region. In the wet processing system, vast quantities of POME wastewater are generated which may harm the environment. This study concludes that different cultivation modes, careful species selection and different conditions may improve growth, biomass yield, and productivity of several value added products generated by microalgae growing on wastewater. Other future research should highlight LC-PUFA production, fatty acid and pigments based on species which were not tested on POME before. Thus, more scientific work needs to be done to arrive at other value added products in feasible, sustainable, and economic cultivation systems.

Acknowledgements M.M. Azimatun Nur would like to acknowledge the Ministry of Finance of the Republic of Indonesia and the Indonesia Scholarship Endowment Fund/Lembaga Pengelola Dana Pendidikan (LPDP) for their support.

Open Access This article is distributed under the terms of the Creative Commons Attribution 4.0 International License (http://creativeco mmons.org/licenses/by/4.0/), which permits unrestricted use, distribution, and reproduction in any medium, provided you give appropriate credit to the original author(s) and the source, provide a link to the Creative Commons license, and indicate if changes were made.

\section{References}

1. Abdel-Raouf, N., Al-Homaidan, A.A., Ibraheem, I.B.M.: Microalgae and wastewater treatment. Saudi. J. Biol. Sci. 19, 257-275 (2012)
2. Abdullah, M.A., Ahmad, A., Shah, S.M.U., et al.: Integrated algal engineering for bioenergy generation, effluent remediation, and production of high-value bioactive compounds. Biotechnol. Bioprocess Eng. 21(2), 236-249 (2016)

3. Abeliovich, A., Azov, Y.: Toxicity of ammonia to algae in sewage oxidation ponds. Appl. Enviro. Microbiol. 31(6), 801-806 (1976)

4. Abinandan, S., Shanthakumar, S.: Challenges and opportunities in application of microalgae (chlorophyta) for wastewater treatment: a review. Renew. Sustain. Energ. Rev. 52, 123-132 (2015)

5. Abreu, A.P., Fernandes, B., Vicente, A.A., Teixeira, J., Dragone, G.: Mixotrophic cultivation of Chlorella vulgaris using industrial dairy waste as organic carbon source. Bioresour. Technol. 118, 61-66 (2012)

6. Adams, C., Bugbee, B.: Enhancing lipid production of the marine diatom Chaetoceros gracilis: synergistic interactions of sodium chloride and silicon. J. Appl. Phycol. 26, 1351-1357 (2014)

7. Ahmad, A., Bhat, A.H., Buang, A.: Immobilized Chlorella vulgaris for efficient palm oil mill effluent treatment and heavy metals removal. Desalin. Water treat. 81, 105-117 (2017)

8. Ahmad, A., Shah, S.M.U., Othman, M.F., Abdullah, M.A.: Enhanced palm oil mill effluent treatment and biomethane production by co-digestion of oil palm empty fruit bunches with Chlorella Sp. Canadian J. Chem. Eng. 92, 1636-1642 (2014)

9. Begum, H., Yusof, F.M., Banerjee, S., Khatoon, H., Shariff, M.: Availability and utilization of pigments from microalgae. Crit. Rev. Food Sci. Nutr. 56(13), 2209-22022 (2016)

10. Belkin, S., Boussiba, S.: High internal $\mathrm{pH}$ conveys ammonia resistance in Spirulina platensis. Bioresour. Technol. 38, 167169 (1991)

11. Belotti, G., Caprariis, B.D., Filippis, P.D., Scarsella, M., Verdone, N.: Effect of Chlorella vulgaris growing conditions on biooil production via fast pyrolysis. Biomass Bioenerg. 61, 187-195 (2014)

12. Beuckels, A., Smolders, E., Muylaert, K.: Nitrogen availability influences phosphorus removal in microalgae-based wastewater treatment. Water Res. 77, 98-106 (2015)

13. Boelen, P., Van Dijk, R., Damste, J.S.S., Rijpstra, W.I., Buma: A.G.J.: on the potential application of polar and temperate marine microalgae for EPA and DHA production. AMB Express. 3(26), 1-9 (2013)

14. Borowitzka, M.A.: Commercial production of microalgae: ponds, tanks, tubes and fermenters. J. Biotechnol. 70, 313-321 (1999)

15. Botebol, H., Sutak, R., Scheiber, I., Blaiseau, P.-L., Bouget, F.-Y., Camadro, J.-M., Lesuisse, E.: Different iron sources to study the physiology and biochemistry of iron metabolism in marine micro-algae. Biometals. 27, 75-88 (2014)

16. Boussiba, S., Richmond, A.: C-phycocyanion as a storage protein in the blue green alga Spirulina platensis. Arch. Microbiol. 125, 143-147 (1980)

17. BPS: Indonesian Oil Palm Statistics. (BPS Statistics Indonesia, Jakarta, 2015), pp. 7-8

18. Brzezinski, M.A.: The Si:C:N ratio of marine diatioms: interspecific variability and the effect of some environmental variables. J. Phycol. 21, 347-357 (1985)

19. Cai, M., Li, Z., Qi, A.: Effects of iron electrovalence and species on growth and astaxanthin production of Haematococcus pluvialis. Chin. J. Ocean Limnol. 27, 370-375 (2009)

20. Carvalho, A.P., Monteiro, C.M., Malcata, F.X.: Simultaneous effect of irradiance and temperature on biochemical composition of the microalga Pavlova lutheri. J. Appl. Phycol. 21, 543-552 (2009)

21. Chen, C.Y., Zhao, X.Q., Yen, H.W., Ho, S.H., Cheng, C.L., Lee, D.J., Bai, F.W., Chang, J.S.: Microalgae-based carbohydrates for biofuel production. Biochem. Eng. J. 78, 1-10(2013) 
22. Chen, F.: High cell density culture of microalgae in heterotrophic growth. Trends Biotechnol. 14, 421-426 (1996)

23. Cheng, H., Tian, G., Liu, J.: Enhancement of biomass productivity and nutrients removal from pretreated piggery wastewater by mixotrophic cultivation of Desmodesmus sp. CHX1. Desalin. Water Treat. 51, 7004-7011 (2013)

24. Cho, S., Lee, D., Luong, T.T., Park, S., Oh, Y.K., Lee, T.: Effects of carbon and nitrogen sources on fatty acid contents and composition in the green microalga Chlorella sp. 227. J. Microbiol. Biotechnol. 21, 1073-1080 (2011)

25. Cho, S., Luong, T.T., Lee, D., Oh, Y., Lee, T.: Reuse of effluent water from a municipal wastewater treatment plant in microalgae cultivation for biofuel production. Bioresour. Technol. 102, 8639-8645 (2011)

26. Choix, F.J., Bashan, Y., Mendoza, A., de-Bashan, L.E.: Enhanced activity of ADP glucose pyrophosphorylase and formation of starch induced by Azospirillum brasilense in Chlorella vulgaris. J. Biotechnol. 177, 22-34 (2014)

27. Chu, H.Q., Tan, X.B., Zhang, Y.L., Yang, L.B., Zhao, F.C., Guo, J.: Continuous cultivation of Chlorella pyrenoidosa using anaerobic digested starch processing wastewater in the outdoors. Bioresour. Technol. 185, 40-48 (2015)

28. Coelho, R.S., Vidotti, A.D.S., Reis, E.M., Franco, T.T.: High cell density cultures of microalgae under fed-batch and continuous growth. Chem. Eng. Trans. 38, 313-318 (2014)

29. Darley, W.M., Volcani, B.E.: Role of silicon in diatom metabolism. Exp. Cell Res. 58, 334-342 (1969)

30. Delgadillo-Mirquez, L., Filipa, L., Behnam, T., Dominique, P.: Nitrogen and phosphate removal from wastewater with a mixed microalgae and bacteria culture. Biotechnol. Rep. 1, 118-126 (2016)

31. DEM.: Malaysia sewage and industrial effluent discharge standards. Department of Environment of Malaysia, Malaysia. (2011)

32. Devi, M.P., Mohan, S.V.: $\mathrm{CO}_{2}$ supplementation to domestic wastewater enhances microalgae lipid accumulation under mixotrophic microenvironment: effect of sparging period and interval. Bioresour. Technol. 112, 116-123 (2012)

33. Dickinson, K.E., Whitney, C.G., McGinn, P.J.: Nutrient remediation rates in municipal wastewater and their effect on biochemical composition of the microalga Scenedesmus sp. AMDD. Algal. Res. 2, 127-134 (2013)

34. Ding, G.T., Yaakob, Z., Takriff, M.S., Jailani, S., Muhammad, S.A.R.: Biomass production and nutrients removal by a newlyisolated microalgal strain Chlamydomonas sp in palm oil mill effluent (POME). Int. J. Hydrogen Energ. 41, 4888-4895 (2016)

35. Erdoğan, A., Zeliha, D., Dalay, M.C., Ahmet, E.E.: Fucoxanthin content of Cylindrotheca closterium and its oxidative stress mediated enhancement. Turkish J. Fish Aquat. Sci. 16, 491-498 (2016)

36. Erickson, R.J.: An evaluation of mathematical models for the effects of $\mathrm{pH}$ and temperature on ammonia toxicity to aquatic organisms. Water Res. 19(8), 1047-1058 (1985)

37. Espinosa-Gonzalez, I., Parashar, A., Bressler, D.C.: Heterotrophic growth and lipid accumulation of Chlorella protothecoides in whey permeate, a dairy by-product stream, for biofuel production. Bioresour. Technol. 155, 170-176 (2014)

38. Fan, J., Cui, Y., Wan, M., Wang, W., Li, Y.: Lipid accumulation and biosynthesis genes response of the oleaginous Chlorella pyrenoidosa under three nutrition stressors. Biotechnol. Biofuels. 7, 1-17 (2014)

39. FAOSTAT.: Crops processed database [Internet]. Food and Agriculture Organization of the United Nations (2016). http://faost at3.fao.org/browse/Q/QD/E. Accessed 14 October 2016

40. Fernandes, B.D., Mota, A., Teixeria, J.A., Vicente, A.A.: Continuous cultivation of photosynthetic microorganisms: approaches, applications and future trends. Biotechnol. Adv. 33(6), 1228 1245 (2015)

41. Fu, W., Wichuk, K., Brynjolfsson, S.: Developing diatoms for value-added products: challenges and opportunities. New Biotech. 32(6), 547-551 (2015)

42. Gao, F., Li, C., Yang, Z.-H., Zeng, G.-M., Feng, L.-J., Liu, J.-Z., Liu, M., Cai, H.-W.: Continuous microalgae cultivation in aquaculture wastewater by a membrane photobioreactor for biomass production and nutrients removal. Ecol. Eng. 92, 55-61 (2016)

43. García-Cañedo, J.C., Cristiani-Urbina, E., Flores-Ortiz, C.M., et al.: Batch and fed-batch culture of Scenedesmus incrassatulus: effect over biomass, carotenoid profile and concentration, photosynthetic efficiency and non-photochemical quenching. Algal Res. 13, 41-52 (2016)

44. Gonçalves, A.L., Simões, M., Pires, J.C.M.: The effect of light supply on microalgal growth, $\mathrm{CO}_{2}$ uptake and nutrient removal from wastewater. Energ. Convers. Manage. 85, 530-536 (2014)

45. Graham, J.M., Graham, L.E., Zulkifly, S.B., Pfleger, B.F., Hoover, S.W., Yoshitani, J.: Freshwater diatoms as a source of lipids for biofuels. J. Ind. Microbiol. Biotechnol. 39(3), 419-428 (2012)

46. Graverholt, O.S., Eriksen, N.T.: Heterotrophic high-cell-density fed-batch and continuous-flow cultures of Galdieria sulphuraria and production of phycocyanin. Appl. Microbiol. Biotechnol. 77(1), 69-75 (2007)

47. Grobbelaar, J.U.: Algal nutrition. In: Richmond, A. (ed.) Handbook of Microalgal Culture: Biotechnology and Applied Phycology, (Blackwell, Iowa, 2004), pp. 97-115

48. Guedes, A.C., Amaro, H.M., Malcata, F.X.: Microalgae as sources of high added-value compounds a brief review of recent work. Biotechnol. Prog. 27(3), 597-613 (2011)

49. Gupta, P.L., Choi, H.J., Lee, S.: Enhanced nutrient removal from municipal wastewater assisted by mixotrophic microalgal cultivation using glycerol. Environ. Sci. Pollut. Res. 23, 10114-10123 (2016)

50. Habib, M.A.B., Yusoff, F.M., Phang, S.M., Ang, K., Mohammed, S.: Nutritional values of chironomid larvae grown in palm oil mill effluent and algal culture. Aquaculture. 158, 95-105 (1997)

51. Habib, M.A.B., Yusoff, F.M., Phang, S.M., Kamarudin, M.S., Mohamed, S.: Growth and nutritional values of Molina micrura fed on Chlorella vulgaris grown in digested palm oil mill effluent. Asian Fish Sci. 16, 107-119 (2003)

52. Hadiyanto, H., Christwardana, M., Soetrisnanto, D.: Phytoremediations of palm oil mill effluent (POME) using aquatic plants and microalgae for biomass production. J. Env. Sci. Technol. 6(2), 79-90 (2013)

53. Hadiyanto, H., Nur, M.M.A., Hartanto, G.D.: Cultivation of Chlorella sp. as biofuel sources in Palm Oil Mill Effluent (POME). Int. J. Renew. Energ. Dev. 1(2), 45-49 (2012)

54. Hadiyanto, H., Nur, M.M.A.: Lipid extraction of microalga Chlorella sp. cultivated in palm oil mill effluent (POME) medium. World Appl. Sci. J. 31(5), 959-967 (2014)

55. Halim, F.T.A., Guo, X., Su, G., Ngee, H.L., Zeng, X., He, N., Lin, L., Danquah, M.K.: Sustainable microalgae-based palm oil mill effluent treatment process with simultaneous biomass production. Canadian J. Chem. Eng. 94(10), 1848-1854 (2016)

56. Hasanudin, U., Sugiharto, R., Haryanto, A., Setiadi, T., Fujie, K.: Palm oil mill effluent treatment and utilization to ensure the sustainability of palm oil industries. Water Sci. Technol. 72(7), 1089-1095 (2015)

57. He, Q., Haijian, Y., Lei, W., Chunxiang, H.: Effect of light intensity on physiological changes, carbon allocation and neutral lipid accumulation in oleaginous microalgae. Bioresour. Technol. 191, 219-228 (2015)

58. Ho, S.H., Chen, C.Y., Chang, J.S.: Effect of light intensity and nitrogen starvation on $\mathrm{CO}_{2}$ fixation and lipid/carbohydrate 
production of an indigenous microalgae Scenedesmus obliquus CNW-N. Bioresour. Technol. 113, 244-252 (2012)

59. Hodaifa, G., Martinez, M.E., Sanchez, S.: Influence of $\mathrm{pH}$ on the culture of Scenedesmus obliquus in olive-mill wastewater. Biotechnol. Bioprocess. Eng. 14(6), 856-860 (2009)

60. Hongyang, S., Yalei, Z., Chunmin, Z., Xuefei, Z., Jinpeng, L.: Cultivation of Chlorella pyrenoidosa in soybean processing wastewater. Bioresour. Technol. 102(21), 9884-9890 (2011)

61. Hosseini, S.E., Wahid, M.A.: Pollutant in palm oil production process. J. Air Waste Manage. Assoc. 65(7), 773-781 (2015)

62. Ilkhur, A., Cirik, S., Goksan, T.: Effect of light intensity, salinity and temperature on growth in Camalt strain of Dunaliella viridis and Teodoresco from Turkey. J. Biol. Sci. 8, 1356-1359 (2008)

63. Indriyati, A.: Potensi limbah industri kelapa sawit di Indonesia. Manaje. Tek. Ling. 4 (1), 93-103 (2008)

64. Iwuagwu, J.O., Ugwuanyi, J.O.: Treatment and valorization of palm oil mill effluent through production of food grade yeast biomass. J. Waste Manage. (2014) https://doi. org/10.1155/2014/439071

65. Jebali, A., Acién, F.G., Gómez, C., Fernández-Sevilla, J.M., Mhiri, N., Karray, F., Dhouib, A., Molina-Grima, E., Sayadi, S.: Selection of native Tunisian microalgae for simultaneous wastewater treatment and biofuel production. Bioresour. Technol. 198, 424-430 (2015)

66. Ji, F., Zhou, Y., Pang, A., Ning, L., Rodgers, K., Liu, Y., Dong, R.: Fed-batch cultivation of Desmodesmus sp. in anaerobic digestion wastewater for improved nutrient removal and biodiesel production. Bioresour. Technol. 184, 116-122 (2015)

67. Jiang, L., Ji, Y., Hua, W., Pei, H., Nie, C., Ma, G., Song, M.: Adjusting irradiance to enhance growth and lipid production of Chlorella vulgaris cultivated with monosodium glutamate wastewater. J. Photochem. Photobiol. B. 162, 619-624 (2016)

68. Joint, I., Henriksen, P., Fonnes, G.A., Bourne, D., Thingstad, T.F., Riemann, B.: Competition for inorganic nutrients between phytoplankton and bacterioplankton in nutrient manipulated mesocosms. Aquat. Microb. Ecol. 29, 145-159 (2002)

69. Kamyab, H., Din, M.F.M., Hosseini, S.E., et al.: Optimum lipid production using agro-industrial wastewater treated microalgae as biofuel substrate. Clean Techol. Environ. Policey. 18(8), 2513-2523 (2016)

70. Kang, R., Wang, J., Shi, D., Cong, W., Cai, Z., Ouyang, F.: Interactions between organic and inorganic carbon sources during mixotrophic cultivation of Synechococcus sp. Biotechnol Lett. 26, 1429-1432 (2004)

71. Khoo, C.G., Woo, M.H., Yury, N., Lam, M.K., Lee, K.T.: dual role of Chlorella vulgaris in wastewater treatment for biodiesel production: growth optimization and nutrients removal study. J. Jap. Institute. Energ. 96, 290-299 (2017)

72. Koller, M., Muhr, A., Braunegg, G.: Microalgae as versatile cellular factories for valued products. Algal Res. 6, 52-63 (2014)

73. Korner, S., Das, S.K., Veenstra, S., Vermaat, J.E.: The effect of $\mathrm{pH}$ variation at the ammonium/ammonia equilibrium in wastewater and its toxicity to Lemna gibba. Aquat. Bot. 71(1), 71-78 (2001)

74. Kumar, V., Muthuraj, M., Palabhanvi, B., Das, D.: Synchronized growth and neutral lipid accumulation in Chlorella sorokiniana FC6 IITG under continuous mode of operation. Bioresour. Technol. 200, 770-779 (2016)

75. Lam, M.K., Lee, K.T.: Renewable and sustainable bioenergies production from palm oil mill effluent (POME): win-win strategies toward better environmental protection. Biotechnol. Adv. 29(1), 124-141 (2011)

76. Lee, E., Jalalizadeh, M., Zhang, Q.: Growth kinetic models for microalgae cultivation: a review. Algal Res. 12, 497-512 (2015)
77. Lee, K., Lee, C.G.: Effect of light/dark cycles on wastewater treatments by microalgae. Biotechnol. Bioproc. Eng. 6, 194-199 (2001)

78. Lee, S.H., Ahn, C.Y., Jo, B.H., Lee, S.A., Park, J.Y., An, K.G., Oh, H.M.: Increased microalgae growth and nutrient removal using balanced N:P ratio in wastewater. J. Microbiol. Biotechnol. 32(1), 92-98 (2013)

79. Lenihan-Geels, G., Bishop, K.S., Ferguson, L.R.: Alternative sources of omega-3 fats: can we find a sustainable substitute for fish? Nutrients. 5(4), 1301-1315 (2013)

80. Li, Y., Chen, Y., Chen, P., Min, M., Zhou, W., Martinez, B., Zhu, J., Ruan, R.: Characterization of a microalgae Chlorella sp. well adapted to highly concentrated municipal wastewater for nutrient removal and biodiesel production. Bioresour. Technol. 102(8), 5138-5144 (2011)

81. Li, Y., Zhou, W., Hu, B., Min, M., Chen, P., Ruan, R.: Effect of light intensity on algal biomass accumulation and biodiesel production for mixotrophic strains Chlorella kessleri and Chlorella protothecoide cultivated in highly concentrated municipal wastewater. Biotechnol. Bioeng. 109(9), 2222-2229 (2012)

82. Li, Yu-Ru, Wen-Tien, T., Yi-Chyun, H., Meng-Zhi, X., JenJeng, C.: Comparison of autotrophic and mixotrophic cultivation of green microalgal for biodiesel production. Energy Procedia. 52, 371-376 (2014)

83. Liew, W.L., Kassim, M.A., Muda, K., Loh, S.K., Affam, A.C.: Conventional methods and emerging wastewater polishing technologies for palm oil mill effluent treatment: a review. J. Environ. Manage. 149, 222-235 (2015)

84. Liu, B.H., Lee, Y.K.: Secondary carotenoids formation by the green alga Chlorococcum sp. J. Appl. Phycol. 12, 301-307 (2000)

85. Loera-Quezada, M.M., Leyva-González, M.A., López-Arredondo, D., Herrera-Estrella, L.: Phosphite cannot be used as a phosphorus source but is non-toxic for microalgae. Plant Sci. 231, 124-130 (2015)

86. Louhasakul, Y., Cheirsilp, B., Prasertsan, P.: Valorization of palm oil mill effluent into lipid and cell-bound lipase by marine yeast yarrowia lipolytica and their application in biodiesel production. Waste Biomass Valor. 7(3), 417-426 (2016)

87. Ma, X., Zheng, H., Addy, M., Anderson, E., Liu, Y., Chen, P., Ruan, R.: Cultivation of Chlorella vulgaris in wastewater with waste glycerol: Strategies for improving nutrients removal and enhancing lipid production. Bioresour. Technol. 207, 252-261 (2016)

88. Marchetti, A., Maldonado, M.T.: Iron. In: Borowitzka, M.A., Beardall, J., Raven, J.A. (eds.) The Physiology of Microalgae, pp. 233-280. Springer, Switzerland (2016)

89. Marcilhac, C., Sialve, B., Pourcher, A.-M., Ziebal, C., Bernet, N., Béline, F.: Digestate color and light intensity affect nutrient removal and competition phenomena in a microalgal-bacterial ecosystem. Water Res. 64, 278-287 (2014)

90. Markou, G., Chatzipavlidis, I., Georgakakis, D.: Cultivation of Arthrospira (Spirulina) platensis in olive-oil mill wastewater treated with sodium hypochlorite. Bioresour. Technol. 112, 231 - 241 (2012)

91. Markou, G., Nerantzis, E.: Microalgae for high-value compounds and biofuels production: a review with focus on cultivation under stress conditions. Biotechnol. Adv. 8, 1532-1542 (2013). https://doi.org/10.1016/j.biotechadv.2013.07.011

92. Markou, G.: Fed-batch cultivation of Arthrospira and Chlorella in ammonia-rich wastewater: optimization of nutrient removal and biomass production. Bioresour. Technol. 193, 35-41 (2015)

93. McGinn, P.J., Dickinson, K.E., Park, K.C., Whitney, C.G., MacQuarrie, S.P., Black, F.J., Frigon, J.-C., Guiot, S.R., O`Leary, S.J.B.: Assessment of the bioenergy and 
bioremediation potentials of the microalga Scenedesmus sp. AMDD cultivated in municipal wastewater effluent in batch and continuous mode. Algal Res. 1(2), 155-165 (2012)

94. Md-Din, M.F., Ponraj, M., Van Loosdrecht, M., et al.: Utilization of palm oil mill effluent for polyhydroxyalkanoate production and nutrient removal using statistical design. Int J. Environ. Sci. Technol. 11(3), 671-684 (2014)

95. Milledge, J.J.: Commercial application of microalgae other than as biofuels: a brief review. Rev. Environ. Sci. Biotechnol. 10(1), 31-41 (2011)

96. Minhas, A.K., Hodgson, P., Barrow, C.J., Adholeya, A.: A review on the assessment of stress conditions for simultaneous production of microalgal lipids and carotenoids. Front. Microbiol. 7, 546 (2016)

97. Mojaat, M., Pruvost, J., Foucault, A., Legrand, J.: Effect of organic carbon sources and $\mathrm{Fe}^{2+}$ ions on growth and $\beta$-carotene accumulation by Dunaliella salina. Biochem. Eng. J. 39(1), 177-184 (2008)

98. Molina-Grima, E., Belarbi, E.-H., Acien-Fernandez, F.G., Robles-Medina, A., Chisti, C.: Recovery of microalgal biomass and metabolites: process options and economics. Biotechnol. Adv. 20, 491-515 (2003)

99. Morales-Sánchez, D., Tinoco-Valencia, R., Kyndt, J., Martinez, A.: Heterotrophic growth of Neochloris oleoabundans using glucose as a carbon source. Biotechnol. Biofuels (2013) https://doi. org/10.1186/1754-6834-6-100

100. Mumtaz, T., Abd-Aziz, S., Rahman, N.A., et al.: Pilot-scale recovery of low molecular weight organic acids from anaerobically treated palm oil mill effluent (POME) with energy integrated system. African J. Biotechnol. 7(21), 3900-3905 (2008)

101. Mutanda, T., Karthikeyan, S., Bux, F.: The utilization of postchlorinated municipal domestic wastewater for biomass and lipid production by chlorella spp. under batch conditions. Appl. Biochem. Biotechnol. 164(7), 1126-1138 (2011)

102. Neoh, C.H., Yahya, A., Adnan, R., Majid, A., Ibrahim, Z.: Z.: Optimization of decolorization of palm oil mill effluent (POME) by growing cultures of Aspergillus fumigatus using response surface methodology. Environ. Sci. Pollut. Res. Int. 20(5), 29122923 (2013)

103. Noue, J.D.L., Gillas, L., Daniel, P.: Algae and waste water. J. Appl. Phycol. 4, 247-254 (1992)

104. Nur, M.M.A., Hadiyanto, H.: Enhancement of Chlorella vulgaris biomass cultivated in POME medium as biofuel feedstock under mixotrophic conditions. J. Eng. Technol. Sci. 47(5), 487-497 (2015)

105. Nur, M.M.A., Kristanto, D., Setyoningrum, T.M., Budiaman, I.G.S.: Utilization of microalgae cultivated in palm oil mill wastewater to produce lipid and carbohydrate by employing microwave- assisted irradiation. Recent. Innov. Chem. Eng. 9(2), 107-116 (2016)

106. Nur, M.M.A., Setyoningrum, T.M., Budiaman, I.G.S.: Potency of Botryococcus braunii cultivated on palm oil mill effluent wastewater as a source of biofuel. Enviro. Eng. Res. 22(4), 417-425 (2017)

107. Nwuche, C.O., Ekpo, D.C., Eze, C.N., Aoyagi, H., Ogbonna, J.C.: Use of palm oil mill effluent as medium for cultivation of Chlorella sorokiniana. Br. biotechnol J 4(3): 305-316 (2014)

108. Ogbonna, J.C., Masui, H., Tanaka, H.: Sequential heterotrophic/ autotrophic cultivation - an efficient method of producing Chlorella biomass for health food and animal feed. J. Appl. Phycol. 9(4), 359-366 (1997)

109. Olguin, E.J.: Dual purpose microalgae-bacteria-based systems that treat wastewater and produce biodiesel and chemical products within a Biorefinery. Biotechnol. Adv. 30, 1031-1046 (2012)
110. Olguín, E.J., Galicia, S., Angulo-Guerrero, O., Hernández, E.: The effect of low light flux and nitrogen deficiency on the chemical composition of Spirulina sp. (Arthrospira) grown on digested pig waste. Bioresour. Technol. 77(1), 19-24 (2001)

111. Pacheco, M.M., Hoeltz, M., Moraes, M.S., Schneider, R.C.: Microalgae: cultivation techniques and wastewater phycoremediation. J. Environ. Sci. Health A Tox. Subst. Environ. Eng. 50(6), 585-601 (2015)

112. Park, S., Kim, J., Park, Y., Son, S., Cho, S., Kim, C., Lee, T.: Comparison of batch cultivation strategies for cost-effective biomass production of Micractinium inermumNLP-F014 using a blended wastewater medium. Bioresour. Technol. 234, 432-438 (2017)

113. Perez-Garcia, O., Bashan, Y., Puente, M.E.: Organic carbon supplementation of sterilized municipal wastewater is essential for heterotrophic growth and removing ammonium by the microalga chlorella vulgaris. J. Phycol. 47(1), 190-199 (2011)

114. Perez-Garcia, O., Bashan, Y.: Microalgal heterotrophic and mixotrophic culturing for bio-refining: from metabolic routes to techno-economics. In: Prokop, A., Bajpai, R.K., Zappi, M.E. (eds.) Algal Biorefineries. Products and Refinery Design, vol. 2, pp. 61-131. Springer International Publishing, Switzerland (2015)

115. Perez-Garcia, O., de-Bashan, L.E., Hernandez, J.-P., Bashan, Y.: Efficiency of growth and nutrient uptake from wastewater by heterotrophic, autotrophic, and mixotrophic cultivation of Chlorella vulgaris immobilized with Azospirillum brasilense. J. Phycol. 46, 800-812 (2010)

116. Perrine, Z., Negi, S., Sayre, R.T.: Optimization of photosynthetic light energy utilization by microalgae. Algal Res. 1(2), 134-142 (2012)

117. Pittman, J.K., Dean, A.P., Olumayowa, O.: The potential of sustainable algal biofuel production using wastewater resources. Bioresour. Technol. 102, 17-25 (2011)

118. Poh, P.E., Yong, W-J., Chong, M.F.: Palm oil mill effluent (POME) characteristic in high crop season and the applicability of high-rate anaerobic bioreactors for the treatment of POME. Ind. Eng. Chem. Res. 49(22), 11732-11740 (2010)

119. Prajapati, S.K., Kaushik, P., Malik, A., Vijay, V.K.: Phycoremediation coupled production of algal biomass, harvesting and anaerobic digestion: possibilities and challenges. Appl Environ. Microbiol. 31, 1408-1425 (2013)

120. Qin, L., Shu, Q., Wang, Z., et al.: Cultivation of chlorella vulgaris in dairy wastewater pretreated by UV irradiation and sodium hypochlorite. Appl. Biochem. Biotechnol. 172, 1121$1130(2014)$

121. Rajkumar, R., Takriff, M.S.: Nutrient removal from anaerobically treated palm oil mill effluent by Spirulina platensis and Scenedesmus dimorphus. Der Pharmacia Lettre. 7(7), 416-421 (2015)

122. Ramanna, L., Guldhe, A., Rawat, I., Bux, F.: The optimization of biomass and lipid yields of Chlorella sorokiniana when using wastewater supplemented with different nitrogen sources. Bioresour. Technol. 168, 127-135 (2014)

123. Ras, M., Steyer, J., Bernard, O.: Temperature effect on microalgae: a crucial factor for outdoor production. Rev Environ Sci Biotechnol. 12, 153-164 (2013)

124. Reynolds, C.: Ecology of Phytoplankton, p. 550. Cambridge University Press, Cambridge (2006)

125. Roessler, P.G.: Effects of silicon deficiency on lipid composition and metabolism in the diatom Cyclotella cryptica. J. Phycol. 24, 394-400 (1988)

126. Ruiz, J., Álvarez-Díaz, P.D., Arbib, Z., Garrido-Pérez, C., Barragán, J., Perales, J.A.: Performance of a flat panel reactor in the continuous culture of microalgae in urban wastewater: prediction 
from a batch experiment. Bioresour. Technol. 127, 456-463 (2013)

127. Ruiz, J., Giuseppe, O., Jeroen, deV., Rouke, B., Philippe, W., Reith, J.H., Michel, H.M.E., Dorinde, M.M.K., René, H.W., Maria, J.B.: Towards industrial products from microalgae. Energ Enviro Sci (2016) https://doi.org/10.1039/c6ee01493c

128. Rupani, P.F., Singh, R.P., Ibrahim, M.H., Esa, N.: Review of current palm oil mill effluent (POME) treatment methods: vermicomposting as a sustainable practice. World Appl. Sci. J. 11, 70-81 (2010)

129. Ryu., K., Rorrer, G.L.: Changes in total lipid contents of marine diatom Nitzschia frustulum at various temperatures under Si deficiency. Korean J. Chem. Eng. 27, 567-569 (2010)

130. Salama, el-S., Kim, H.C., Abou-Shanab, R.I., Ji, M.K., Oh, Y.K., Kim, S.H., et al.: Biomass, lipid content, and fatty acid composition of freshwater Chlamydomonas mexicana and Scenedesmus obliquus grown under salt stress. Bioprocess Biosyst. Eng. 36, 827-833 (2013)

131. Salama, el-S., Abou-Shanaba, R.A., Kim, J.R., Lee, S., Kim, S.H., Oh, S.E., Kim, H.C., Roh, H.S., Jeon, B.H.: The effects of salinity on the growth and biochemical properties of Chlamydomonas mexicana GU732420 cultivated in municipal wastewater. Environ. Technol. 35(9-12), 1491-1498 (2014)

132. Salla, A.C.V., Margarites, A.C., Seibel, F.I., Holz, L.C., Brião, V.B., Bertolin, T.E., Colla, L.M., Costa, J.A.V.: Increase in the carbohydrate content of the microalgae Spirulina in culture by nutrient starvation and the addition of residues of whey protein concentrate. Bioresour. Technol. 209, 133-141 (2016)

133. Sasongko, N.A., Noguchi, R., Ahamed, T., Takaigawa, T.: Introduction of integrated energy plantation model for microalgae-using palm oil mill effluent (POME). J Jpn. Inst. Energ. 6, 561-570 (2015)

134. Shah, S., Ahmad, A., Othman, M.F., Abdullah, M.A.: Enhancement of lipid content in Isochrysis galbana and Pavlova lutheri using palm oil mill effluent as an alternative medium. Chem. Eng. Trans. 37, 733-738 (2014)

135. Shah, S.M.U., Ahmad, A., Othman, M.F., Abdullah, M.A.: Effects of palm oil mill effluent media on cell growth and lipid content of Nannochloropsis oculata and Tetraselmis suecica. Int. J. Green Energ. 13(2), 200-207 (2016)

136. Shi, J., Pandey, P.K., Franz, A.K., Deng, H., Jeannotte, R.: Chlorella vulgaris production enhancement with supplementation of synthetic medium in dairy manure wastewater. AMB express. 6(15), 1-9 (2016)

137. Simas-Rodrigues, C., Helena, D.M., Villela, A.P.M., Luiza, G.M., Pio, C., Angela, P.T.: Microalgae for economic applications: advantages and perspectives for bioethanol. J Exp Bot. 66(14), 4097-4108 (2015). https://doi.org/10.1093/jxb/erv130

138. Singh, J., Gu, S.: Commercialization potential of microalgae for biofuels production Renew. Sustain. Energ. Rev. 14, 25962610 (2010)

139. Singh, S., Bhushan, K.N., Banerjee, U.C.: Bioactive compounds from cyanobacteria and microalgae: an overview. Criti. Rev. Biotechnol. 25(3), 73-95 (2005)

140. Singh, S.P., Singh, P.: Effect of temperature and light on the growth of algae species: a review. Renew. Sust. Energ. Rev. 50, 431-444 (2015)

141. Sloth, J.K., Wiebe, M.G., Eriksen, N.T.: Accumulation of phycocyanin in heterotrophic and mixotrophic cultures of the acidophilic red alga Galdieria sulphuraria. Enzyme Microb. Technol. 38(1-2), 168-175 (2006)

142. Subramanian, S., Barry, A.N., Pieris, S., Sayre, R.T.: Comparative energetics and kinetics of autotrophic lipid and starch metabolism in chlorophytic microalgae: implications for biomass and biofuel production. Biotechnol. Biofuels (2013) https ://doi.org/10.1186/1754-6834-6-150
143. Suharyanto, T.-P., Permatasari, S., Syamsu, K.: Production of Spirulina platensis in continous photobioreactor using palm oil mill effluent media. Menara Perkebunan. 82(1), 1-9 (2014)

144. Sukumaran, P., Nulit, R., Zulkifly, S., Halimoon, N., Omar, H., Ismail, A.: Potential of fresh POME as a growth medium in mass production of Arthrospira platensis. Int. J. Current Micorbiol. Appl. Sci. 3(4), 235-250 (2014)

145. Tabassum, S., Zhang, Y., Zhang, Z.: An integrated method for palm oil mill effluent (POME) treatment for achieving zero liquid discharge—a pilot study. J Clean Prod. 95, 148-155 (2015)

146. Takagi, M., Yoshida, T.: Effect of salt concentration on intracellular accumulation of lipids and triacylglyceride in marine microalgae Dunaliella cells. J. Biosci. Bioeng. 101, 223-226 (2006)

147. Takriff, M.S., Zakaria, M.Z., Sajab, M.S., Teow, Y.H.: Pre-treatments anaerobic palm oil mill effluent (POME) for microalgae treatment. Indian J. Sci. Technol. 9(21), 1-8 (2016)

148. Tjahjono, A.E., Hayama, Y., Kakizono, T., Terada, Y., Nishio, N., Nagai, S.: Hyper-accumulation of astaxanthin in a green alga Haematococcus pluvialis at elevated-temperatures. Biotech. Lett. 16, 133-138 (1994)

149. Tong, S.L., Jaafar, A.B.: Waste to energy: methane recovery from anaerobic digestion of palm oil mill effluent. Energy Smart. 4, $1-8$ (2004)

150. Ummalyma, S.B., Sukumaran, R.K.: Cultivation of microalgae in dairy effluent for oil production and removal of organic pollution load. Bioresour. Technol. 165, 295-301 (2014)

151. Vairappan, C.S., Yen, A.M.: Palm oil mill effluent (POME) cultured marine microalgae as supplementary diet for rotifer culture. J Appl Phycol. 20(5), 603-608 (2008)

152. Vanthoor-Koopmans, M., Wijffels, R., Barbosa, M., Eppink, M.: Biorefinery of microalgae for food and fuel. Bioresour. Technol. 135, 142-149 (2013)

153. Van-Wagenen, J., De Francisci, D., Angelidaki, I.: Comparison of mixotrophic to cyclic autotrophic/heterotrophic growth strategies to optimize productivity of Chlorella sorokiniana. J. Appl. Phycol. 27(5), 1775-1782 (2015)

154. Wang, J., Yang, H., Wang, F.: Mixotrophic cultivation of microalgae for biodiesel production: status and prospects. Appl. Biochem. Biotechnol. 172, 3307-3329 (2014)

155. Wang, M., Wu, Y., Li, B., Dong, R., Lu, H., Zhou, H., Cao, W.: Pretreatment of poultry manure anaerobic-digested effluents by electrolysis, centrifugation and autoclaving process for Chlorella vulgaris growth and pollutants removal. Environ. Technol. 36(5-8), 837-843 (2015)

156. Wang, M.Z., Zhu, Z.W., Cao, W., Zhang, Y.: Effect of synthetic wastewater by electrochemical pretreatment on Chlorella vulgaris growth and nutrients removal. Adv. Mat. Res. 666, 33-42 (2013)

157. Wang, Y., Bing, H., Zhilan, S., Yi-Feng, C.: Chemically enhanced lipid production from microalgae under low sub-optimal temperature. Algal Res. 16, 20-27 (2016)

158. Wang, Y., Chiu, S.Y., Ho, S.H., Liu, Z., Hasunuma, T., et al.: Improving carbohydrate production of Chlorella sorokiniana NIES-2168 through semi-continuous process coupled with mixotrophic cultivation. Biotechnol. J. 11(8), 1072-1081 (2016)

159. Wang, Y., Liu, Z., Qin, S.: Effects of iron on fatty acid and astaxanthin accumulation in mixotrophic Chromochloris zofingiensis. Biotechnol. Lett. 35, 351-357 (2013)

160. Wen, Z.Y., Chen, F.: Heterotrophic production of eicosapentaenoic acid by the diatom Nitzschia laevis: effects of silicate and glucose. J. Ind. Microbiol. Biotechnol. 25, 218-224 (2000)

161. Wen, Z.Y., Chen, F.: Perfusion culture of the diatom Nitzschia laevis for ultra-high yield of eicosapentaenoic acid. Process Biochem. 38(4), 523-529 (2002) 
162. Wijffels, R.H., Barbosa, M.J.: An outlook on microalgal biofuels. Science. 329(5993), 796-799 (2010)

163. Wilhelm, C., Büchel, C., Fisahn, J., Goss, R., Jakob, T., LaRoche, J., Lavaud, J., Lohr, M., Riebesell, U., Stehfest, K., Valentin, K., Kroth, P.G.: The regulation of carbon and nutrient assimilation in diatoms is significantly different from green algae. Protist. 157, 91-124 (2006)

164. Woolard, C.R., Irvine, R.L.: Treatment of hypersaline wastewater in the sequencing batch reactor. Wat. Res. 29(4), 1159-1168 (1995)

165. Wu, T.Y., Mohammad, A.W., Jahim, J., Anuar, N.: Pollution control technologies for the treatment of palm oil mill effluent (POME) through end-of-pipe processes. J. Environ. Manage. 91, 1467-1490 (2010). https://doi.org/10.1016/j.jenvm an.2010.02.008

166. Xia, L., Junfeng, R., Haijian, Y., Qiaoning, H., Delu, Z., Chunxiang, $\mathrm{H} .: \mathrm{NaCl}$ as an effective inducer for lipid accumulation in freshwater microalgae Desmodesmus abundans. Bioresour. Technol. 161, 402-409 (2014)

167. Xie, Y., Jin, Y., Zeng, X., Chen, J., Lu, Y., Jing, K.: Fed-batch strategy for enhancing cell growth and C-phycocyanin production of Arthrospira (Spirulina) platensis under phototrophic cultivation. Bioresour. Technol. 180, 281-287 (2015)

168. Xu, F., Cai, Z.L., Cong, W., Ouyang, F.: Growth and fatty acid composition of Nannochloropsis sp. grown mixotrophically in fed-batch culture. Biotechnol. Lett. 26(17), 1319-1322 (2004)

169. Yamaoka, Y., Takimura, O., Fuse, H., Kamimura, K.: $\beta$-Carotene production by Dunaliella salina in fed-batch and semicontinuous cultures under nutrient supplement. Seibutsu-kogaku. 72, 111114 (1994)

170. Yan, C., Zhang, L., Luo, X., Zheng, Z.: Effects of various LED light wavelengths and intensities on the performance of purifying synthetic domestic sewage by microalgae at different influent C/N ratios. Ecol. Eng. 51, 24-32 (2013)

171. Zainal, A., Yaakob, Z., Takriff, M.S., Rajkumar, R., Ghani, J.A.: Phycoremediation in anaerobically digested palm oil mill effluent using cyanobacterium, Spirulina platensis. J. Biobased Mater. Bio. 6, 1-6 (2012)

172. Zhang, C., Zhang, Y., Zhuang, B., Zhou, X.: Strategic enhancement of algal biomass, nutrient uptake and lipid through statistical optimization of nutrient supplementation in coupling Scenedesmus obliquus-like microalgae cultivation and municipal wastewater treatment. Bioresour. Technol. 171, 71-79 (2014)

173. Zhang, Q., Zhan, J.-J., Hong, Y.: The effects of temperature on the growth, lipid accumulation and nutrient removal characteristics of Chlorella sp. HQ. Desalin. Water Treat. 57(22), 10403-10408 (2016)

174. Zhao, Z., Song, X., Wang, W., Xiao, Y., Gong, Z., Wang, Y., Zhao, Y., Yu, C., Mengyuan, M.: Influences of iron and calcium carbonate on wastewater treatment performances of algae based reactors. Bioresour. Technol. 216, 1-11 (2016)

175. Zhu, Y.H., Jiang, J.G.: Continuous cultivation of Dunaliella salina in photobioreactor for the production of $\beta$-carotene. Eur. Food Res. Technol. 227, 953-959 (2008) 